Copyright $(\mathcal{C} 2018$ by the Kalmyk Scientific Center of the Russian Academy of Sciences

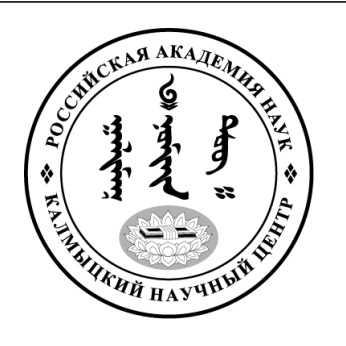

Published in the Russian Federation

Oriental Studies (Previous Name: Bulletin of the Kalmyk Institute for

Humanities of the Russian Academy of Sciences)

Has been issued as a journal since 2008

ISSN: 2619-0990; E-ISSN: 2619-1008

Vol. 38, Is. 4, pp. 135-155, 2018

DOI 10.22162/2619-0990-2018-38-4-135-155

Journal homepage: https://kigiran.elpub.ru

УДК $398.21+398.22+801.83$

\title{
Критерии характеристики жанра богатырской сказки и основные отличия богатырских сказок от образцов эпоса*
}

Алексей Алексеевич Бурыкин ${ }^{1}$

${ }^{1}$ доктор филологических наук, доктор исторических наук, ведущий научный сотрудник, отдел монгольской филологии, Калмыцкий научный центр РАН (358000, Россия, г. Элиста, ул. им. И. К. Илишкина, д. 8). ORCID: 0000-0002-9119-2698. E-mail: albury@mail.ru

Аннотация. Статья посвящена проблеме соотношения героического эпоса и богатырской сказки. Эти две формы фольклора во многих традициях весьма близки друг другу и проявляют множество черт сходства. Поставленная проблема является значимой в равной мере для жанровой идентификации отдельных образцов текстов и для обсуждения исторических взаимосвязей богатырской сказки и эпоса. Как принято считать, богатырская сказка могла быть такой формой, которая непосредственно предшествовала ранним формам эпоса или представляла собой одну из таких форм.

В настоящее время ученые отмечают, что богатырская сказка в отдельных примерах являет собой результат позднейшей трансформации эпических форм, обусловленной ослаблением позиций эпоса в традиции, сокращением количества собственно эпических образцов, постепенной утратой техники эпического песенного исполнения и т. д. Автор придерживается мнения, согласно которому эпос и сказка, в частности и богатырская сказка, существовали изначально как самостоятельные формы, различающиеся по отношению к изображаемой реальности: сказка — заведомый вымысел по определению, эпос — возможная, потенциальная правда.

Издание объемного собрания калмыцких богатырских сказок (М., 2017) позволяет более отчетливо представить себе основные признаки жанра богатырской сказки и, главное, определить содержательные отличия этого жанра от образцов эпоса, конкретно — от «Джангара».

Внутри калмыцкой фольклорной традиции богатырские сказки показывают существенные отличия от песен «Джангара», с которыми такие сказки сопоставимы по сюжетам и мотивам. Автор обращает внимание как на общие жанровые отличия «Джангара» и богатырской сказки, так и на различия этих форм в калмыцкой традиции.

По итогам исследования, богатырская сказка как жанровая группа текстов в целом сохраняет структуру волшебной сказки, определяемую по пропповским функциям, герой богатырской сказки отличается от эпического героя индивидуальностью действий и личными целями действия, в отличие от Джангара, он не имеет социоорганизующей функции.

Ключевые слова: фольклор, фольклористика, жанры, эпос, сказки, богатырские сказки, калмыки

*Исследование проведено в рамках государственной субсидии - проект "Фольклор монголоязычных народов: тексты и исследования" (регистрационный номер АААА-А17-117030910099-8). 
Проблема отношений между собственно эпосом и богатырской сказкой, как кажется, относится к числу сложнейших проблем современной фольклористики. Названная проблема, во-первых, представляет собой одну из фундаментальных проблем эпосоведения в характерологическом отношении - в отношении жанровой идентификации текстов; во-вторых, она же значима и для исторической типологии эпо$\mathrm{ca}$, поскольку по умолчанию до недавнего времени архаические формы эпоса связывались по происхождению, или по существу отождествлялись с богатырской сказкой. B-третьих, проблема богатырской сказки как ранней формы эпоса затрагивает основы сказковедения в сфере классификации жанровых разновидностей сказки и классификации сказок как жанра в целом.

В существующей довольно объемной литературе вопрос о соотношении героического эпоса и богатырской сказки оказался запутанным за счет целого ряда теоретических построений историко-типологического и стадиально-типологического характеpa, в рамках которых для характеристики разных форм эпоса и сказки различными исследователями принимались разные решения. Кроме этого, принципиально важно иметь в виду разграничение формы эпоса и богатырской сказки в разных этнических традициях, где необходимо принимать во внимание как сложившуюся номенклатуру произведений у исполнителей и слушателей, так и объективные характеристики текстов по сюжетам, мотивам, поэтике, а также процессы взаимодействия этих жанров. Конкретизируем нашу мысль: каждый сказитель знает, что́ именно он сказывает; каждый слушатель знает и понимает, что́ он слушает, но не всегда составители и исследователи отдают себе отчет в том, что́ именно они издают и что именно они изучают.

В формальном отношении отграничение богатырской сказки от эпоса для большинства известных нам традиций в Евразии, конкретно - в центральной Азии и связанных с ней историко-культурных областях - выглядит достаточно просто. Главное различие сказки и эпоса - то, что богатырская сказка рассказывается прозой или, что встречается нечасто, содержит песенные или стихотворные вставки. В то же время эпическое сказание поется той или иной формой пения или же исполняется чередованием прозы в повествовании и стихов - в диалогах персонажей.
Между формами эпоса и богатырской сказки наблюдается любопытная жанроидентифицирующая зависимость: если в эпосе проза чередуется со стихами, то сказка рассказывается прозой; если эпос поется, тогда богатырская сказка может чередовать прозу со стихами и тем выделяется по своей поэтике из других групп сказок (впрочем, например, у тунгусских народов песенные диалоги встречаются в сказках о животных).

Традиционная номенклатура, используемая исполнителями и знатоками - это весьма распространенный и достаточно хороший критерий разграничения эпоса и богатырской сказки. Казалось бы, если эпос и сказка называются разными терминами, и богатырская сказка не выделяется из других групп сказок, то интересующая нас проблема отсутствует вообще. Однако этот критерий не всегда эффективен тогда, когда эпос и сказка называются одним термином, как нимкан у эвенов и нимнгакан у эвенков (разграничение нимнгаканма нимнгакан и гумэ нимнгакан выявлено весьма поздно); даже под термин олонгхо в якутской и зависимых от нее традициях подводятся разные фольклорные формы - эпическое произведение и сказка, а названия собственно сказок кэnсээн и остуоруйа не различаются [Смирнов 2008: 22]. Первый термин в данном случае - собственно якутский, второй русское заимствование, что не удивительно, если иметь в виду довольно заметное русское влияние на сюжетику и структуру якутских сказок [Дьяконова 1990].

Если рассматривать личность исполнителя в приложении к проблеме эпоса и богатырской сказки, между типами и группами исполнителей отмечается существенная разница. Эпический сказитель как личность всегда масштабнее сказочника и всегда имеет в социуме какие-то особые функции (см. [Функ 2005; Дампилова 2008]). Если исполнителям эпоса посвящены специальные монографии и разделы монографий [Лорд 1994: 24-42; Райхл 2008: 106; Путилов 1997; Чичеров 1982], и они выделяются в особую категорию в социуме как олонхосуты, манасчи, джангарчи и т. п., то исследование личности исполнителя сказок сопряжено с невероятными трудностями и охватит круг лиц от исполнителя одной сказки до исполнителя группы сказок, попавшей в «авторский» сборник сказок. «Авторские» сборники сказок - жанр, известный немногочисленными образцами в 
русской традиции (сборники А. К. Барышниковой (Куприянихи), Ф. П. Господарева, И. Ф. Ковалева, М. М. Коргуева, А. Н. Корольковой, М. А. Сказкина) и почти исключительный в традиции народов Севера (книга эскимосских сказок «Сказочник Кивагмэ» К. С. Сергеевой [Сергеева 1968]; здесь не учитываются авторские сборники в самозаписи, имеющие широкое распространение). В начале XXI в. эта форма стала распространенной в издании калмыцких сказок по архивным материалам, а также образцов повествовательного фольклора хантов и манси в местных изданиях ${ }^{1}$.

Посмотрим для сопоставления на список исполнителей тувинских сказок и преданий, собранных Эрикой Таубе: «15 пастухов (один из них, бывший шаман, занимался еще и кузнечным делом), 3 столяра, 6 доярок, 2 мастера молокозавода, 1 сплавщик, 1 полевая сторожиха, 1 охотник (бывший лама), 1 учитель, 1 студент, 3 ученика, 1 старик (когда-то был один из самых богатых людей Цэнгэла), 2 домашние хозяйки» [Сказки и предания 1994: 25].

Любопытные перспективы обещает выявление различий в образцах героического эпоса и богатырских сказок на уровне формальной структуры текста разных жанров, однако это направление исследований «фольклорные жанры как типы текстов» [Бурыкин 1990] в применении к нарративным текстам развивается очень медленно. Даже анализ сказки по пропповским функциям, знакомый каждому исследователю и много обещающий даже современным фольклористам, как-то потерялся во времени и не имеет продолжения, публикации по этой проблеме очень немногочисленны: см., например: [Кербелите 1995; Неклюдов 1995; Рафаева 1995; 1998; Цийль 1995; Структура волшебной сказки 2001].

В отечественной литературе по фольклористике в какой-то момент возобладало

${ }^{1}$ Подобный тип изданий удобен тем, что он дает в руки исследователям новые материалы и позволяет исследовать особенности исполнительской практики каждого носителя традиции. Однако при работе с такими изданиями учеными трудно согласовать как раз жанровые и сюжетные особенности новых текстов с теоретическими решениями специалистов и особенностями фольклорной традиции в целом, ибо «исполнительские» сборники фиксируют в основном поздние состояния традиции, материал которой вызывает сомнения [Рафаева 2007]. мнение В. М. Жирмунского, согласно которому богатырская сказка объявляется предшественницей героического эпоса, хотя и у автора идеи имелись на этот счет оговорки в отношении эволюционирующих сюжетов, внутрижанровой динамики эпических повествований и преобразования целых традиций [Жирмунский 1974: 201-223]. С мнением В. М. Жирмунского солидаризируется Е. М. Мелетинский [Мелетинский 2004: 77-78, 80, 85, 87, 92 и мн. др.; см. однако: [Мелетинский 2004: 230, 354]. Ученый пишет: «Богатырская сказка, вырастающая из недр первобытного сказочного фольклора, не всегда и не везде выделяется в особую жанровую разновидность. В период начинающегося разложения первобытнообщинного строя появляются мотивы одиночества героя, действующего без участия рода. Эти мотивы создают специфический фон для более яркой обрисовки исключительных богатырских сил центрального персонажа. Часто богатырская сказка выделяется песенной формой исполнения и некоторыми стилистическими чертами, предвосхищающими эпический стиль. <..> богатырская сказка - это также еще не героический эпос, поскольку общественное, коллективистское значение подвига богатыря ограничено выполнением им в индивидуальном деянии общественных родовых норм. В богатырской сказке отсутствует настоящий эпический фон, изображение общенародных судеб» [Мелетинский 2004: 91].

Нам придется здесь остановиться, чтобы избавиться от социологических фантомов прошлого века, на которых держалась методология исследования. Вчитаемся во фразу: «...общественное, коллективистское значение подвига богатыря ограничено выполнением им в индивидуальном деянии общественных родовых норм. Изучение материала преподносит нам десятки и сотни текстов, где отсутствуют какие-либо иные персонажи, не предусмотренные „шестеркой Проппа-Греймаса“"» [Пропп 1928: 88-89; Структурализм 1975: 451]. Данный набор из шести персонажей (к нему уже В. Я. Проппом был добавлен ложный герой [Пропп 1928: 89] - позиция, весьма перспективная для обсуждения увеличения персонажей нарратива). У нас нет инструментов, чтобы при анализе акциональности героя отличить действия, направленные на его собственное жизнеобеспечение (куда входят и поиски брачного партнера) 
и на личную безопасность, от действий с социальной мотивацией. Змееборческие, драконоборческие мотивы тоже не являются социально мотивированными: это как бы преобразованная охотничья практика. Вхождение героя в сеть потестарных связей (женитьба на дочери высокопоставленного лица) - мотив, свидетельствующий скорее против «рода», чем в его пользу. В общем, с некоторой иронией можно сказать, что «род» как древняя социальная единица, ни отцовский, ни материнский, в «шестерке Проппа-Греймаса» не находит себе места.

С. Ю. Неклюдов полагает, что богатырские сказки могут как предшествовать эпосу, так и при определенных условиях представлять собой позднейшую стадию в его эволюции [Неклюдов 1975; 1984: 48 (со ссылкой на Д. Кара), 132 (со ссылкой на Л. Лёринца)], о переходе улигеров - образцов эпоса в сказки говорят и другие авторы [Бардаханова 2011: 20]. В. Т. Сарангов считает калмыцкие богатырские сказки продуктом своеобразной эрозии одной из форм эпоса [Сарангов 1997], этот тезис в калмыцкой фольклористике выглядит принципиально новым по сравнению с исторической концепцией эпоса у А. Ш. Кичикова.

Недавно высказана весьма оригинальная точка зрения, предполагающая независимый (в жанровом отношении) генезис эпоса и богатырской сказки из единого источника: «Первоначальным истоком их (произведений о богатырях. - $A$. Б.) являются, очевидно, всевозможные легенды и мифологические рассказы о первобытных великанах-богоборцах (ср. трагическую судьбу народа Ад, широко отраженную в Коране), которые в глубокой древности были хорошо известны у многих народов, и не только у тюркоязычных или мусульманских. В гораздо более поздние эпохи на этой основе возникают и формируются богатырские сказки или богатырские поэмы, на базе которых формируются хорошо нам известные раннесредневековые и средневековые сказания об Алпамыше» [Урманче 2015: 22]. Сходная точка зрения высказана по калмыцким материалам Ц. Б. Селеевой [Селеева 2015: 154].

Значимость противопоставления эпоса и богатырской сказки для общей исследовательской концепции явствует из того, что как в научных классификациях, так и в исполнительских характеристиках различаются две разных формы эпоса. К их числу от- носятся сжатые и пространные формы эпоса [Хойслер 1960: 317], длинный и короткий эпос [Райхл 2008: 128]; «пешая» и «конная» формы эпоса [Функ 2005: 37], «малый эпос» или «краткий эпос» в противоположность собственно эпосу (Ринчиндордж) (см. [Сказки и предания 1994: 46]).

В тунгусской, конкретно в эвенкийской, фольклорной традиции стало принятым различать такие формы, как нимнгакама нимнгакан ('поющийся нимнгакан') и гумэ нимнгакан ('рассказываемый нимнгакан') [Варламов, Варламова 2011: 38], при этом появляется возможность сравнивать образцы разных жанровых форм, имеющие один и тот же сюжет [Варламов, Варламова 2011: 39].

В русской и шире славянской традиции, где былевой эпос и сказки четко противопоставлены по всем параметрам, богатырские сказки выделяются из массива сказок по характеристикам персонажей. Богатырскими в славянской традиции считаются сказки, «героями которых являются люди, наделенные необыкновенной силой» [Восточнославянский фольклор 1993: 314]. То же можно, вероятно, сказать и о сказках народов Балтии (латыши, литовцы).

А. Ш. Кичиков, характеризуя калмыцкую эпическую традицию и оценивая ее как фольклорист, отмечает: «Как видим, термины „тууль“ и „улигер“ имеют прямое отношение к древнеойратскому, древнекалмыцкому эпосу, определяя и характер его бытования, и специфику его исполнения. Все это дает нам возможность обозначить эпический жанр, предшествовавший «Джангару», рабочим термином тууль-улигер, или тууль-улигерный эпос, учитывая при этом употребительность компонентов данного определения у современных родственных калмыкам народов - ойратов и монголов (тууль) и бурят (улигер)» [Кичиков 1992: 11]. Однако далее А. Ш. Кичиков в своем исследовании обращается не к калмыцким богатырским сказкам (которых известно довольно много), а к реконструкции «тууль-улигеров» [Кичиков 1992: 13]. Это совсем иная исследовательская задача, нежели определение характеристик богатырской сказки даже в применении к калмыцкой фольклорной традиции.

Д. А. Функ пишет: «Богатырская сказка - наиболее часто отделяется от героического эпоса по меньшей степени историчности, наличию волшебного, мифоло- 
гического фона сюжетов и образов и менее широкой общественно-политической, народной и государственной перспективы, не выходящей за рамки патриархальной семьи и рода, либо по „особому“ тематическому диапазону и сюжетной структуре. Встречается и иное определение: богатырская сказка - это позднейшее сказочное переложение эпических сюжетов» [Функ 2005: 36]. Сказанное абсолютно верно, но при чем тут патриархальная семья и род - опять, как и в случае с Е. М. Мелетинским, непонятно. Обратим внимание, что по какой-то причине никто из исследователей до сих пор не начал выявлять и описывать темы рода и патриархальной семьи в богатырской сказке, и даже чисто «женские» фольклорные и у́же - эпические сюжеты, в небольшом количестве присутствующие почти всюду), до сих пор не удостоены должного внимания со стороны эпосоведов. Возможно, причина этого заключена в осознаваемой бесперспективности социального конструирования на словесном материале.

М. Ф. Бухуров отмечает: «богатырской сказкой мы будем называть прозаические эпические художественные произведения, основанные на нарочитом вымысле, где главным героем является богатырь, достигающий сказочной цели, благодаря, прежде всего, физической силе. При этом роль чудесного богатырского коня, оружия и других чудесных предметов оценивается как подчиненная и второстепенная по отношению к физической силе героя» [Бухуров 2015: 32; Закирова 2017: 31].

Если исследования по составу образцов якутского эпоса олонхо ведутся весьма успешно, то якутская богатырская сказка пользуется гораздо меньшим вниманием ученых. История собирания якутских сказок освещена в литературе [Смирнов 2008], где особо отмечен вклад П. А. Ойунского в изучение якутского фольклора, однако богатырские сказки, сходные по персонажам и мотивам с олонхо, требуют внимания, вопервых, в контексте якутской фольклорной традиции, во-вторых, в сфере взаимодействия якутского фольклора и фольклора эвенков и эвенов.

Яркий образец якутской богатырской сказки - сказка «Удюргай-Батыр»: «На зелёной мураве, около речки быстротечной, среди белых берёзок стоял ветхий домик. В этом домике жили старик со старухой» [Хaрузина 1898: 174]. Далее рассказывается о рождении у героев младенца из березового нароста (откуда имя героя), о том, как он, не имея глаз, обретает две пары глаз от змеи и орла, по-разному показывающие мир, видит истинную сущность богача и змеи [Харузина 1898: 174-193].

Вот начало якутской сказки «СордохайБогатырь»: «В то время, когда существовали на земле беспутные неразумные якуты, жил славный храбрый богатырь по имени Сордохай. Он был великан, в плечах шире сажени, высотою до трех с половиной сажен. Его золотистые кудрявые волосы вились изпод шапки. Дом его был построен из чистого золота. < ..> Сордохай жил один; у него не было ни жены, ни детей. Он обходился без всякой прислуги. В углу стоял большой очаг, в котором горел постоянный огонь, о котором никто не заботился» [Овчинников 1908: 1]. Хорошим примером якутской богатырской сказки является текст «Славный богатырь и злая Нэгэй-тугут» [Якутские сказки 1990: 47-64].

Вместе с тем сказки «Энгкээбил и Сээкэрэ» и «Старик Букуйдаан с гнутой-согнутой рогатиной» [Якутские народные сказки 2008: 283-289, 289-291], хотя и содержат весьма редкие мотивы, но по форме весьма кратки для подлинных богатырских сказок - можно сказать, что это какой-то вид пародий на богатырские сказки, своего рода фольклорный образец сервантесовского «Дон-Кихота» 1 .

Хорошо известны богатырские сказки в бурятском фольклоре. Исследователи, не стремясь к теоретизированию, тонко подмечают: «Возникновение и формирование таких сказок в известной мере несомненно связано с угасанием улигеров, их жанровой трансформацией (процесс разрушения бурятских улигеров был отмечен в начале XX в. Ц. Ж. Жамцарано). Отдельные повествования о баторах стали передаваться в прозе. Происходил процесс постепенного перехода части улигерных сюжетов в сказочный жанр. Но было неверно усматривать в богатырских сказках только переделку

1 Здесь на конкретном материале просматривается закономерность, выразительно различающая богатырскую сказку и эпос - богатырская сказка допускает любое отношение к своему тексту, включая пародирование, причем как внутри фольклора, так и за его пределами (ср. некоторые сказки М. Е. Салтыкова-Щедрина или «Песню про дикого вепря» В. С. Высоцкого. Эпос не пародируется в принципе. 
улигеров. Есть основания считать, что богатырские повествования - издавна существующая традиционная разновидность бурятских сказок. У них во многом общий с улигерами арсенал художественно-изобразительных приемов и мотивов» [Бурятские волшебные сказки 1993: 19]. С. С. Бардаханова пишет также: «Богатырские сказки, которые возникают в наши дни на основе улигерных сюжетов, в современном бытовании представляют собой в основном прозаические повествования. Однако редко, но все же встречаются стихотворные сказки, как, например «Гэсэр Богдо-хубун», в исполнении эхиритского сказителя С. Сонтохонова. Данная сказка, органически связанная с улигером, отличается от него лаконичностью сюжета, стройностью композиции. В ней действует предельно ограниченное число персонажей: Гэсэр и три его богатыря» [Бардаханова 2011: 20]. Наблюдения бурятских фольклористов показывают, что эпос и богатырские сказки заметно различаются по такому параметру, как темп действия, определяющий формально объем повествования - значительный для эпического произведения (законченное сказание или песнь в составе, например, такого эпоса, как «Джангар»).

Аналогичные явления, по-видимому, определяющие характер взаимоотношений между определенными формами эпоса и сказкой, характерны для фольклорной традиции алтайцев. Т. М. Садалова высказывается так: «Взаимодействие сказок с героическими сказаниями также имеет свою специфику. Например, первоисточниками отдельных сюжетов сказок стали „разрушенные“ произведения из жанра сказаний (№ 31 „Санаа-Мерген“). Или же, наоборот, их первоисточниками были сказки, которые затем усложнились до более развернутых произведений и обрели жанровые черты богатырских сказок. Так, в одном из вариантов сказки „Брат Боодой-Кёкшин и сестра Боодой-Коо“ . .. наблюдаем „облачение“ сказочного сюжета в поэтическую ткань эпического сказания (ФМ273 (11)). Текст сказки имеет стихотворную форму» [Алтайские народные сказки 2002: 37].

Не вполне понятна ситуация с местом богатырских сказок среди жанров фольклора у тувинцев. В одном из сборников в отдельную группу выделены две богатырские сказки «Богатырь Тевене-Мёге и конь его Демир-Шилги» и «Бесстрашный Хан-
Хулюк» [Тувинские народные сказки 1971: 13-55], однако Эрика Таубе отмечает, что сами тувинцы не различают волшебных и богатырских сказок [Сказки и предания 1994: 31]. В имеющемся материале богатырские сказки имеют запевные слова «Ааалаяний! Жил однажды маленький мальчик с серой лошадью-двухлеткой, с которой клочьями свисала прошлогодняя шерсть, маленький мальчик с кудлатыми волосами и зубками, как гниды» [Сказки и предания 1994: 54]. Начало некоторых богатырских сказок сходно с зачинами эпоса: «Давным-давно, в те времена, когда возник весь мир в своей красе и совершенстве, с молодыми деревьями в тридцать саженей высотой, с травой осокой в три сажени длиной, жил да был некий хан» [Сказки и предания 1994: 134], такие же экспозиции встречаются в волшебных сказках: «Это было тогда, / Когда внешнее море было еще болотом; / Это было тогда, / Когда гора Сюмбер была еще холмом; / Это было тогда, / Когда пышное сандаловое дерево было еще листиком - / жили тогда старик со старухой. До пятидесяти лет не было у них детей» [Сказки и предания 1994: 216].

Анализируя группу богатырских сказок алтайских тувинцев, Эрика Таубе отмечает: «Довольно жесткая схема связывает содержание богатырских сказок с отдельными фазами шаманских ритуалов. 1. Случается несчастье. 2. Герой отправляется на поиски врага, чтобы победить и уничтожить его. 3. Преодолев множество препятствий и избежав множество опасностей - иногда и после временного поражения, он побеждает врага. 4. Герой возвращается, и восстанавливается первоначальное состояние» [Сказки и предания 1994: 43]. Напомним, что Е. С. Новик предлагала выводить форму волшебной сказки в целом из шаманского ритуала [Новик 1984].

Как сообщают новейшие издания, в калмыцкой фольклористике принято подразделять сказки на ахр туульс 'короткие сказки', к которым относятся сказки о животных и бытовые сказки, и ут туульс 'длинные сказки' - в эту группу входят богатырские сказки (баатрлг тууль) и волшебные сказки (сидтә тууль) [Калмыцкие богатырские сказки 2017: 7].

До недавнего времени богатырские сказки калмыков привлекали внимание исследователей, в основном фольклористовкалмыковедов, лишь спорадически и в основном в связи с проблемами эпосоведения 
[Борджанова 1980; 1987; Сарангов 1989; 1990а; 1990б; 1997; 2015; Манджиева 2015a; 20156].

В процессе работы над томом свода (см. [Манджиева 2017в]) и в рамках изучения эпоса «Джангар» получила освещение история изучения и издания богатырских сказок [Манджиева 2015в], формулы эпоса и богатырской сказки [Манджиева 2016a, 2017б; Селеева 2004], структурные элементы эпоса «Джангар» и богатырской сказки в связи с проблемой сказочных и эпических формул и тем [Манджиева 2001; 2004; Хабунова 2006], отдельные мотивы, общие для эпоса и богатырских сказок [Мутляева 1978; 1982; Селеева 2008; Манджиева 2015г; 2015д; 2016а; 2016б; 2017а], анализ отдельных текстов [Манджиева 2017в]. Новые перспективы для сравнительных исследований калмыцкого эпоса «Джангар» и богатырских сказок открывает указатель тем эпоса «Джангар» в разных версиях [Селеева 2012; 2013; 2017].

Издание фундаментального собрания калмыцких богатырских сказок значительно продвинуло вперед изучение этого интереснейшего жанра, находящегося на грани сказки и эпоса. К большому сожалению, в рамках концепции Свода калмыцкого фольклора в данном томе помещены лишь 25 текстов богатырских сказок, представляющих в основном образцы, не известные ранее. Вместе с тем за пределами этого тома остались многие богатырские сказки, изданные в переводах на русский язык: «Батыр Дамбин-Улан и храбрый конь его Давшурин-Хурдун-Хара» [Медноволосая девушка 1964: 11-25], «Эрин-Сян-Сеняка» [Медноволосая девушка 1964: 25-37], «Богатырь Шарада» [Калмыцкие народные ... 1978: 48-52], «Добрый Овше» [Калмыцкие народные ... 1978: 38-43], «Храбрый Мазан» [Калмыцкие народные ... 1978: 126-130], «Хан Бюрюн Тегес» [Сандаловый ларец 2003: 46-56], «Гэсэр» [Сандаловый ларец 2003: 94-97], «Младший сын хана АрджиБурджи» [Сандаловый ларец 2003: 98-104], «Богатырь Хорца», «Легенда о том, как завладел Эдг царством хана Джаным», и некоторые другие. Ряд текстов богатырских сказок, не вошедший в наш перечень, рассмотрен В. Т. Саранговым [Сарангов 2015].

$\mathrm{У}$ ойратов Синьцзяна зафиксированы такие богатырские сказки: «Babuq bātur» («Бабуг-батыр»); «Malzan Ulān bātur» («Батыр Малзан Улан»); «Bam ulān bātur xortu moүoi-du bariqdaqsan-ni» («O том, как Бам Улан-батыр поймался ядовитой змее»);

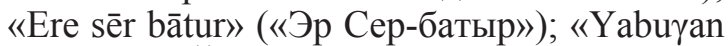
Mergen» («Йобогон Мерген») и др. Наряду с этими образцами Б. В. Меняев находит в образцах фольклора синцзянских калмыков «тууль улигеры»: тууль-улигеры «Arban tabutai Aral Mergen» («Пятнадцатилетний Арал Мерген»), «Cereq-in caүān xān» («Белый хан войска»), «Üküši ügei töröqsen Üren tüben хān» («Бессмертный Урен Тубинхан»), «Xān Cenggel tayiǰi» («Хан Ценгел тайджи»), «Гаng хara tebke» («Ган Хара Тебке»), «Ezen sayin zērde moritai ere-in sayin Mimilceq» («Лучший из мужей Мимилцег с рыжим конем») [Меняев 2016]. Этот массив текстов существенно увеличивает массив богатырских сказок, бытующих у калмыков и ойратов, что весьма важно для общей характеристики богатырских текстов в традиции - для сравнения отметим, что богатырские сказки в якутском фольклоре крайне немногочисленны.

А. Ш. Кичиков выделил для богатырской сказки следующие 12 «конструктивных элементов»: 1) бездетные престарелые хан и хатун [старик и старуха]; 2) вымаливание бездетными супругами ребенка; 3) чудесное рождение сына-богатыря; 4) наречение чудеснорожденного младенца; 5) чудесный рост и необыкновенное детство будущего героя; 6) получение героем вести о суженой; 7) нахождение и укрощение предназначенного герою коня; 8) богатырская поездка юного героя за невестой; 9) участие его в состязаниях за невесту; 10) женитьба, получение приданого и обратный путь; 11) поход героя в страну мангусов [захватчиков] за угнанными в плен родителями [народом]; 12) истребление героем мангусов [захватчиков] и возвращение с освобожденными родителями [народом] [Кичиков 1992: 12; Калмыцкие богатырские сказки 2017: 13]. Те же элементы для богатырской сказки отмечают В. Т. Сарангов и Б. Б. Манджиева [Сарангов 2015; Манджиева 2015д], и они же использованы Е. Э. Хабуновой для анализа поэтических констант «Джангара» [Хабунова 2007].

Если говорить о логике исследования и применять дедуктивный подход, исходя из теории вопроса, это построение безупречно, а сами элементы богатырской сказки, о которых писал А. Ш. Кичиков, примерно соответствуют тем единицам, которые ныне известны как «темы» А. Лорда [Лорд 
1994: 83; Селеева 2006], «стилевые константы» [Хабунова 2006: 147] и - при сложной структуре - «тематические блоки» [Селеева 2017]. Однако если исследователь обратится к анализу текстов и будет классифицировать их по признаку присутствия или отсутствия перечисленных элементов, он попадает в весьма затруднительное положение. Здесь достаточно указать на то, что, по наблюдению В. Т. Сарангова, калмыцкие богатырские сказки делятся на две группы: 1) сказки с сюжетообразующими мотивами сватовства героя, а также освобождения захваченных противниками родных героя и их подданных; 2) сюжеты, где герои сами, отправляясь на подвиги, выезжают в стан врага и побеждают его [Сарангов 2015]. Ожидаемо для богатырских сказок, как и для отдельных песен эпоса, противопоставление «герой-завоеватель» и «герой-защитник», с включением героя в разные группы мотивов.

Действительно, мы встречаем богатырские сказки, весьма похожие на модель, выстроенную А. Ш. Кичиковым: «Это случилось давно, очень давно. Жил на земле хан Довджк-Цаган, который семь поколений не воевал. Был у него табун в один миллион голов, который мирно пасся при свете луны. Был у него другой табун в семь миллионов голов, который в сиянии солнца резвился в вольной степи. И был в том табуне один жеребец. Длинные уши и черные губы были у того жеребца. Но не имел наследника старый великий хан.

И вот, наконец, родился прекрасный сын у седовласого хана Довджк на склоне лет. Через сутки сын-богатырь вырос так, что не хватило овчины, чтобы его завернуть. На вторые сутки не хватило и двух овчин, на третьи сутки было мало и трех овчин, на четвертые - четырех овчин, а на пятые сутки - пяти овчин не хватало, чтобы его завернуть. <..> Мать принесла оружие и доспехи его. Надел богатырь сапоги, которые шила тысяча мастеров. Надел на себя семьдесят крепких бешметов один за другим, слева короткую саблю повесил, справа - стальной кинжал. В правую руку взял сплетенную из бычьей шкуры тяжелую плеть. Рукоятку сандаловую сжал, и по пальцам его потек светлый сандаловый сок (Батыр Дамбин-Улан и храбрый конь его Давшурин-Хурдун-Хара) [Медноволосая девушка 1964: 11-12, 17]. По иронии судьбы эта сказка не попала в том Свода, объе- диняющий калмыцкие богатырские сказки.

Посмотрим начальные формулы текста других образцов калмыцких богатырских сказок:

«Давно это было. В нутуке одного хана жили бедные старик со старухой, и были у них трёхногий сивый бык и сын, лежавший в железной колыбели. <.. > (сын говорит:)

— Вот придёт кто-нибудь и спросит моё имя, пусть плохим именем, но нареки меня, - сказал он своему коню» [Калмыцкие богатырские сказки 2017: 79-80].

В этой сказке мотив чудесного рождения опущен, однако в целом начало текста соответствует ожидаемой структуре.

Однако мы находим - и едва ли не чаще - тексты богатырских сказок, имеющие совершенно иное оформление:

«Давно это было. Жил-был хан АрджиБурджи. У него был конь Аавин Аксак Улан. [Этого] Аавин Аксак Улана коня длинный чёрный человек с единственным глазом на макушке украл» [Калмыцкие богатырские сказки 2017: 33].

Здесь при типичном начале богатырской сказки, приоритетность которого показана собранием Свода, деактуализирована тема бездетных супругов.

«Когда-то, в такие же давние времена, владения семидесяти пяти ханов верхнего мира вере своей подчинив, жил богатый хан по имени Дала Цецен, имевший двоих сыновей» [Калмыцкие богатырские сказки 2017: 47]. Здесь начало перекликается с экспозицией эпоса, и отсутствует не только тема родителей героя, но и чудесное рождение.

«Давно это было. Жил Месин Аавы сын, звали его Менкен Харин Чилденгом. Был у него без устали скакавший поджарый [конь] Хара. В чехле находясь, сияние семи светил затмевающее, если вынуть его из чехла, сияние семидесяти светил затмевающее, когда с криком ударишь им, скалу разрушающее, сверкающее, словно лёд, стальное копьё было [у Харин Чилденга]. В трёхлетнем возрасте лишился отца он, в четырёхлетнем возрасте лишился матери он. <..> В трёхлетнем возрасте отца потеряв, в четырёхлетнем возрасте мать потеряв, в семь лет, чтобы найти с кем повоевать, отправился он в путь» [Калмыцкие богатырские сказки 2017: 241].

Герой-сирота в богатырской сказке, в отличие от эпоса, теоретически не предусматривался, хотя это противоречило бы 
единству типа эпического героя и героя богатырской сказки - впрочем, это единство выглядит умозрительным, и к этой проблеме еще придется вернуться. Происхождение богатырского копья героя в тексте не показывается, только плеть герою была изготовлена при жизни его родителей, однако (это понятно из калмыцкого оригинала [Калмыцкие богатырские сказки 2017: 240]) не ими, а кем-то другим.

«Жил богатырь по имени Харти Хара Кюкюл, у которого был косматый буланый скакун. Был у него старший брат ЧилдерБилдер, у которого был скакун без клочка шерсти. Были у него две птицы - скопы и две собаки - Хасар и Басар. Что по земле пробегало - две собаки его ловили, что наверху пролетало - две птицы его ловили. Старший брат его женатым был» [Калмыцкие богатырские сказки 2017: 281]. И старший брат, и животные-помощники появляются в экспозиции при отсутствии первых пяти (!) составляющих богатырской сказки: действие начинается с того, что младший брат покидает дом, после того как он прикоснулся к голове жены старшего брата. Нам не очень хорошо известно, как регламентировались у калмыков отношения младших братьев к женам старших братьев, однако, судя по известным запретам для невесток [Эрдниев 1985: 211-212] и наличию института левирата у калмыков [Батыров 2015], младший брат, как кажется, не допустил ничего недозволенного в сравнении с младшими братьями в реальности и в фольклоре народов Сибири. М. М. Батмаев описал ситуацию, когда старший брат (Дондук-даши) отнял жену Церен-Джал у своего младшего брата Яндыка [Батмаев 1993: 344-345], что по сибирским нормам отношений между старшим и младшим братьями невозможно.

Богатырский пир в литературе по калмыцким богатырским сказкам не называется в числе «обязательных» элементов сказки. Однако этот мотив в их финале нередок: «[Аг-Сахал Богдитин] Сто пять вепрей-богатырей своих вызвав, приказал им: «Созовите всех подданных, устроим большое пиршество. Немедленно отправляйтесь, старшего брата и невестку моих доставьте. Из своих кочевий-родов лучших мужчин и женщин пусть они приведут с собой.

Так все собрались, прибыли и бедные, и сирые. Все пировали, вкушая чай и борцоки, большое пиршество устроив, семью-семь сорок девять суток большим праздничным становищем жили. Десятилетней выдержки арзу распивая, двадцатилетней выдержки хорзу распивая, большие игры, празднества и торжества устроив, пребывали они» [Калмыцкие богатырские сказки 2017: 77]. В этом тексте налицо детали, характерные для эпического пира, однако последний, похоже, отражает некоторые поздние реалии [Бурыкин 2014].

В других сказках финальное описание пира более лаконично: «К поселившемуся у истока реки Буята дядюшке Буянта Цагану вернувшись, справили свадьбу, сорок девять дней под звуки гармони и хура все веселились и счастливы были» [Калмыцкие богатырские сказки 2017: 17$]$.

Финальный пир может быть только обозначен: «Семьдесят дней подряд пировал он, [затем] в спокойствии счастливо жил» [Калмыцкие богатырские сказки 2017: 253].

Встретилось необычное решение сказочного финала, где после пира герой-богатырь занимается дипломатией: «Ехалиехали, домой приехали, собрали народ со всего своего кочевья, устроили большой пир, семью-семь - сорок девять дней, не разбирая день или ночь, шумно пировали. Попировав, Буджин Дава хан взял с собой богатыря Балым Улана, отправился в кочевья пятидесяти [богатырей] Тенгрин Тёгя [Бюса], собрал там множество народа и провозгласил богатыря Балым Улана ханом бывших владений пятидесяти [богатырей] Небесного Тёгя [Бюса]. Объявив ханом богатыря Балым Улана, Буджин Дава хан вернулся домой, оставшись в своих кочевьяхвладениях, жил в счастье и благоденствии» [Калмыцкие богатырские сказки 2017: 129]. Здесь герой - Буджин Дава хан выступает в роли строителя нового государства — той роли, которая описывается для Джангара, главного персонажа одноименного эпоса в известных калмыцких версиях [Селеева 2015: 152-153].

Однозначно не вписывается в конструируемые некоторыми авторами социальные мотивы следующий финал сказки: «Когда он вошел, к нему бросились, причитая: „Родной человек все равно ведь приходит!“‘ - мать и младшая сестра. „О том, что ты придешь за семь дней я узнала“, - так говоря, мать его плакала. Уладжин Мерген: „В этом скверном месте нельзя оставаться, поедем. Свейте веревку“, - сказал и заставил дочь и мать вить веревку. Когда они заканчивали, из табуна своего семьдесят 
необъезженных коней привести попросив, к хвостам семидесяти коней привязал их крепко-накрепко - мать с дочерью разорвало на семьдесят частей. Кочевье свое, не упустив даже желтой собаки, виляющей хвостом, собрав, большого черного муса владения своим цахаром сделав, счастливо он жил» [Калмыцкие богатырские сказки 2017: 339]. Здесь финальный пир отсутствует по понятным причинам: не всякая победа является торжеством.

В некоторых определениях богатырской сказки, претендующих на обобщение, подчеркивается, что герой сказки одерживает победы благодаря собственной физической силе [Бухуров 2015: 32; Закирова 2017: $21-$ 22], хитрость называется как положительная черта эпического героя [Бухуров 2015: 25]. Думается, такая характеристика более подходит для эпического героя, в сфере действия которого сверхъестественные персонажи и их действия занимают намного меньшее место, нежели в богатырских сказках, и как раз эпические герои, даже наделенные какими-либо иррациональными качествами, как богатыри Джангара, по существу не пользуются хитростями в борьбе с врагами. Посмотрим на тексты: «Тогда он <Тегя Бюс>, поверив словам жены, стал входить в дом, но тут спрятавшийся Аман Цаган изловчился и отрубил ему голову, потом столкнул в яму. Так он расправился с ним. Настало время сна. „Я с отцом лягу спать, давно я не спал с отцом“, - сказал Аман Цаган и лег спать с отцом Тёгя Бюса. Поднявшись ночью, он убил отца Тёгя Бюса. Так же он покончил с братьями Тёгя Бюса и его семьями, а сам со своей женой пребывал в счастье и благоденствии [Калмыцкие богатырские сказки 2017: 85]. Еще пример: «„Если можете, аава, утром не вставайте“, - сказал. Богатырь Барс Мерген у дверей вырыл огромную, как в преисподней, яму. - Почему утром коров не выгоняешь! - так ругая мужчину, [один из мусов явился]. - Или ты решил, что вернулся твой богатырь Барс Мерген?... - [мус] хотел было ворваться, но богатырь Барс Мерген срубил ему голову и столкнул в ту огромную яму. Двух братьев его точно так же уничтожил. Пошёл и убил их трех жен» (Калмыцкие богатырские сказки 2017: 105].

Необычным по крайней мере для двух рассмотренных калмыцких сказок является то, что в обоих случаях интересующее нас действие - сооружение ямы-ловушки осуществляется в помещении или в соседстве с входом в помещение. В эпосе такие ситуации, как кажется, невозможны.

Вопрос, который не может не привлечь нашего внимания, - соотносительность композиции эпических произведений и образцов богатырских сказок. Такие явления, как несоотносительность линейной организации текста с хронологией элементов повествования, характерны для песен «Джангара» - биографии богатырей размещены внутри песен, а не в их начале, и родители, и предки богатырей не играют роли в повествовании. В отдельных песнях «Джангара» отмечается смена «точки зрения» повествователя - в тех случаях, когда противник героя сам приходит в ставку Джангара с целью отнять жену, коней и богатырей [Бурыкин 2004]. В калмыцких богатырских сказках случаи смены точки зрения не отмечены. Однако примеры таких текстов встречаются в других традициях: такова алтайская сказка «Башпарак»: «Раньше на Алтае жила семиголовая Дьелбеген. [У нее] одна голова смеется, одна голова плачет, одна голова поет, одна голова спит, одна голова сторожит, одна голова наблюдает, одна голова убивает. Все они были прожорливые.

Однажды, когда человек по имени Башпарак на своей белой лошади распахивал пашню, к нему пришла мошенница Дьелбеген с покачивающимися семью головами» (далее действие совпадает с русской сказкой о Бабе-Яге) [Алтайские народные сказки 2002: 163-173].

Основное внимание исследователей, изучавших проблему соотношения калмыцкого героического эпоса и богатырской сказки, было привлечено к проблеме сходства образцов этих жанров и соответственно потенциального взаимодействия эпоса и богатырской сказки. Неслучайно это приводит к воспроизведению небесспорной, на наш взгляд, идеи генезиса эпоса из богатырской сказки [Селеева 2016]. В то же время состояние проблемы, начиная с жанровой квалификации отдельных текстов и заканчивая дифференцирующими признаками близких жанровых форм, требует большего внимания не к сходствам, достаточно тривиальным как для сказки, так и для эпоса, а к различиям, которые сплошь и рядом оказываются нетривиальными и не лежащими на поверхности. 
Попробуем посмотреть соотношение богатырской сказки и эпоса по тем призна- кам, которые были указаны А. Ш. Кичиковым (см. табл. 1).

Таблица 1. Соотношение тем в калмыцких богатырских сказках и эпосе

\begin{tabular}{|c|c|c|}
\hline Темы & Богатырская сказка & «Джангар» \\
\hline $\begin{array}{l}\text { 1) бездетные престарелые хан и хатун } \\
\text { [старик и старуха] }\end{array}$ & Встречается довольно редко & Отсутствует \\
\hline $\begin{array}{l}\text { 2) вымаливание бездетными супругами } \\
\text { ребенка }\end{array}$ & $\begin{array}{l}\text { Встречается, но не является } \\
\text { обязательным элементом }\end{array}$ & Отсутствует \\
\hline 3) чудесное рождение сына-богатыря & Встречается при наличии темы 1 & $\begin{array}{l}\text { Отсутствует: почти всегда } \\
\text { указывается возраст матери } \\
\text { героя-богатыря }\end{array}$ \\
\hline $\begin{array}{l}\text { 4) наречение чудеснорожденного } \\
\text { младенца }\end{array}$ & $\begin{array}{l}\text { Присутствует при наличии тем } 1 \\
\text { и } 3\end{array}$ & Отсутствует \\
\hline $\begin{array}{l}\text { 5) чудесный рост и необыкновенное } \\
\text { детство будущего героя }\end{array}$ & $\begin{array}{l}\text { Присутствует при наличии тем } 1 \\
\text { и } 3\end{array}$ & Присутствует \\
\hline 6) получение героем вести о суженой & $\begin{array}{l}\text { Присутствует в группе сказок о } \\
\text { добывании жены }\end{array}$ & $\begin{array}{l}\text { В отдельной песне о женитьбе } \\
\text { (?) }\end{array}$ \\
\hline $\begin{array}{l}\text { 7) нахождение и укрощение } \\
\text { предназначенного герою коня }\end{array}$ & $\begin{array}{l}\text { Присутствует тогда, когда герой } \\
\text { по ходу повествования должен } \\
\text { обрести коня }\end{array}$ & $\begin{array}{l}\text { Отсутствует: у богатырей кони } \\
\text { имеются до начала действия. }\end{array}$ \\
\hline $\begin{array}{l}\text { 8) богатырская поездка юного героя за } \\
\text { невестой }\end{array}$ & $\begin{array}{l}\text { Присутствует в сказках о } \\
\text { добывании жены ( } \\
\text { группа } 1 \text { по В. Т. Сарангову) }\end{array}$ & $\begin{array}{l}\text { Присутствует как единичный } \\
\text { эпизод }\end{array}$ \\
\hline 9) участие его в состязаниях за невесту & $\begin{array}{l}\text { Присутствует в сказках о } \\
\text { добывании жены } \\
\text { (группа } 1 \text { по В. Т. Сарангову) }\end{array}$ & $\begin{array}{l}\text { Состязания связаны с } \\
\text { другими событиями: герой } \\
\text { не выигрывает невесту на } \\
\text { состязаниях }\end{array}$ \\
\hline $\begin{array}{l}\text { 10) женитьба, получение приданого и } \\
\text { обратный путь }\end{array}$ & $\begin{array}{l}\text { Присутствует в сказках о } \\
\text { добывании жены } \\
\text { (группа } 1 \text { по В. Т. Сарангову) }\end{array}$ & $\begin{array}{l}\text { Присутствует как единичный } \\
\text { эпизод во всем эпическом } \\
\text { повествовании }\end{array}$ \\
\hline $\begin{array}{l}\text { 11) поход героя в страну мангусов } \\
\text { [захватчиков] за угнанными в плен } \\
\text { родителями [народом] }\end{array}$ & $\begin{array}{l}\text { Присутствует в сказках о } \\
\text { нападении врага (врагов) } \\
\text { (группа } 2 \text { по В. Т. Сарангову) }\end{array}$ & $\begin{array}{l}\text { Составляет сюжет отдельных } \\
\text { песен }\end{array}$ \\
\hline $\begin{array}{l}\text { 12) истребление героем мангусов } \\
\text { [захватчиков] и возвращение с } \\
\text { освобожденными родителями } \\
\text { [народом] }\end{array}$ & $\begin{array}{l}\text { Присутствует в сказках о } \\
\text { нападении врага (врагов) } \\
\text { (группа } 2 \text { по В. Т. Сарангову) }\end{array}$ & $\begin{array}{l}\text { Составляет развитие сюжета } \\
\text { отдельных песен с темой } 11\end{array}$ \\
\hline
\end{tabular}

Уже по этому набору характеристик богатырской сказки и эпоса видно, что эти жанры имеют между собой больше различий, нежели сходств. Частично соотношение этих черт сказки и эпоса отмечались ранее [Бурыкин 2016]. Такие наблюдения можно продолжить на материале композиционных особенностей богатырской сказки и эпоса (см. табл. 2). 


\section{Таблица 2. Соотношение характеристик калмыцких богатырских сказок и эпоса}

\begin{tabular}{|c|c|c|}
\hline Темы & Богатырская сказка & «Джангар»» \\
\hline Фоновая экспозиция & $\begin{array}{l}\text { Обычно формула «Давно это } \\
\text { было», в других традициях - крат- } \\
\text { кие эпосоподобные эскизы хроно- } \\
\text { топа; развернутые экспозиции в } \\
\text { тувинских богатырских сказках }\end{array}$ & $\begin{array}{l}\text { Пролог к версии Ээлян Овла, описания } \\
\text { мира во многих олонхо и эвенкийских } \\
\text { сказаниях (см. [Бурыкин 2017]) }\end{array}$ \\
\hline Локус действия & $\begin{array}{l}\text { Как в жилище, так и на открытой } \\
\text { местности: перемещения по гори- } \\
\text { зонтали и по вертикали (между ми- } \\
\text { рами) равно возможны }\end{array}$ & $\begin{array}{l}\text { В основном на открытой местности: } \\
\text { перемещения по горизонтали и по } \\
\text { вертикали (между мирами) } \\
\text { возможны }\end{array}$ \\
\hline Генеалогия основных героев & $\begin{array}{l}\text { Не обязательна, и не дальше }+1 \\
\text { поколения (родители героя) }\end{array}$ & $\begin{array}{l}\begin{array}{l}\text { Генеалогия богатырей до }+3 \text { или }+4 \\
\text { колена. }\end{array} \\
\end{array}$ \\
\hline $\begin{array}{l}\text { Характер женских } \\
\text { персонажей (мать, сестра, } \\
\text { жена) }\end{array}$ & $\begin{array}{l}\text { Активная роль в повествовании } \\
\text { при их присутствии }\end{array}$ & $\begin{array}{l}\text { Относительно статичная роль: участие в } \\
\text { эпизодах }\end{array}$ \\
\hline $\begin{array}{l}\text { Обстоятельства рождения } \\
\text { героя (при реализации темы) }\end{array}$ & $\begin{array}{l}\text { Рождение у пожилых родителей: } \\
\text { чудесное рождение или обретение }\end{array}$ & $\begin{array}{l}\text { Герой - первый или единственный сын } \\
\text { у женщины в расцвете сил: богатырская } \\
\text { евгеника - уникальная черта «Джанга- } \\
\text { ра» }\end{array}$ \\
\hline Роль потомков героев & $\begin{array}{l}\text { Отсутствует: о детях героя бога- } \\
\text { тырской сказки обычно ничего не } \\
\text { говорится }\end{array}$ & $\begin{array}{l}\text { Сыновья богатырей Джангара уступают } \\
\text { отцам в богатырских качествах (эпиче- } \\
\text { ская константа) [Баркова 2003] }\end{array}$ \\
\hline $\begin{array}{l}\text { История коня - постоянного } \\
\text { помощника героя }\end{array}$ & $\begin{array}{ll}\text { Наследование } \\
\text { появление }\end{array}$ & $\begin{array}{l}\text { «Благородное происхождение», c } \\
\text { указанием на возраст кобылицы-матери }\end{array}$ \\
\hline $\begin{array}{l}\text { Описание подготовки к } \\
\text { походу, надевание одежды и } \\
\text { доспехов }\end{array}$ & $\begin{array}{l}\text { Описания отсутствуют или очень } \\
\text { кратки }\end{array}$ & \begin{tabular}{|llll} 
Описания & пространны & и значимы, \\
содержат & множество \\
развернутые эпитеты & & \\
\end{tabular} \\
\hline Богатырское оружие & $\begin{array}{l}\text { Меч, копье (всего в } 5 \text { текстах Сво- } \\
\text { да), лук. Поэтические описания } \\
\text { нетипичны. Распространен мотив } \\
\text { меткой стрельбы из лука на состя- } \\
\text { заниях, нет чудесных стрел. Нет } \\
\text { эпизодов использования лука в бою }\end{array}$ & $\begin{array}{l}\text { Мечи, копья, другие виды холодного } \\
\text { оружия с подробными описаниями в тек- } \\
\text { сте. У предметов вооружения имеются } \\
\text { имена. } \\
\text { Искусством стрельбы из лука владеют } \\
\text { немногие, есть стрелы с особыми свой- } \\
\text { ствами. Богатырь может быть ранен } \\
\text { стрелой, но не убит }\end{array}$ \\
\hline $\begin{array}{l}\text { Развернутые описания как } \\
\text { поэтический прием }\end{array}$ & $\begin{array}{l}\text { Мало, в основном в подражание } \\
\text { эпосу }\end{array}$ & Основа поэтики эпоса \\
\hline $\begin{array}{l}\text { Место мотивов в структуре } \\
\text { текста }\end{array}$ & $\begin{array}{l}\text { Фиксированное: в соответствии со } \\
\text { структурой сказки }\end{array}$ & $\begin{array}{l}\text { Нефиксированное: мотив не привязан к } \\
\text { месту в повествовании }\end{array}$ \\
\hline $\begin{array}{l}\text { Изображение среднего, } \\
\text { нижнего и верхнего миров } \\
\text { - асимметричное - } \\
\text { симметричное, зеркальное }\end{array}$ & $\begin{array}{l}\text { Асимметричное: верхний и нижний } \\
\text { миры не имеют определенной } \\
\text { организации }\end{array}$ & $\begin{array}{l}\text { Симметричное, зеркальное: миры } \\
\text { изоморфны }\end{array}$ \\
\hline $\begin{array}{l}\text { Инвертированная } \\
\text { композиция: «герой встречает } \\
\text { врага»/ «Враг приходит к } \\
\text { герою» } \\
\end{array}$ & $\begin{array}{l}\text { В калмыцких богатырских сказках } \\
\text { не отмечено; единичные примеры } \\
\text { в других традициях; смена «точки } \\
\text { зрения» отсутствует }\end{array}$ & $\begin{array}{l}\text { Отдельные песни «Джангара»: смена } \\
\text { «точки зрения». }\end{array}$ \\
\hline $\begin{array}{l}\text { Свойства, качества, } \\
\text { способности героя }\end{array}$ & $\begin{array}{lr}\text { Одноплановые, } & \text { есть } \quad \text { «герои- } \\
\text { специалисты», } & \text { помощники } \\
\text { главного героя } & \\
\end{array}$ & $\begin{array}{l}\text { Способности } \\
\text { разнообразны }\end{array}$ \\
\hline $\begin{array}{l}\text { Социальный статус героев } \\
\text { — разный — относительно } \\
\text { одинаковый для } \\
\text { изображаемого социума }\end{array}$ & $\begin{array}{l}\text { Социальный статус героев раз- } \\
\text { личен до контраста и конфликта: } \\
\text { действия героев направлены на } \\
\text { восстановление или приобретение } \\
\text { высшего статуса }\end{array}$ & $\begin{array}{l}\text { Социальный } \quad \text { статус } \quad \text { героев } \\
\text { одинаковыми функциями однороден }\end{array}$ \\
\hline
\end{tabular}




\begin{tabular}{|c|c|c|}
\hline $\begin{array}{l}\text { Система персонажей } \\
\text { - жестко сказочная - } \\
\text { открытая: множество героев } \\
\text { с одинаковыми функциями }\end{array}$ & \begin{tabular}{|lrr} 
Система персонажей & сходна & c \\
пропповской системой персонажей \\
волшебной сказки
\end{tabular} & $\begin{array}{l}\text { Система персонажей открытая: умноже- } \\
\text { ние персонажей приводит к разветвле- } \\
\text { нию сюжета во времени или на одном } \\
\text { синхронном срезе }\end{array}$ \\
\hline $\begin{array}{l}\text { Отношение к реальности: } \\
\text { вымысел - квазиреализм, } \\
\text { возможная правда }\end{array}$ & Заведомый вымысел & Полуправда: изображение возможного \\
\hline Сфера действия героя & 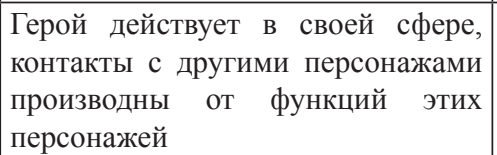 & 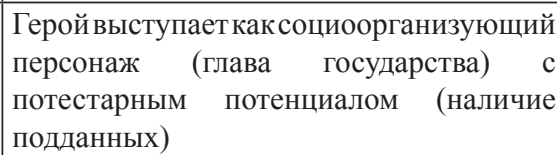 \\
\hline Прег & $\begin{array}{l}\text { Распространенное действие героя, } \\
\text { в том числе превращения вместе с } \\
\text { конем }\end{array}$ & $\begin{array}{l}\text { Способность отдельных персонажей } \\
\text { превращаться в животных и предметы: } \\
\text { превращения вместе с конем }\end{array}$ \\
\hline $\begin{array}{l}\text { Культовые объекты, } \\
\text { поклонения, обряды }\end{array}$ & $\begin{array}{l}\text { Постройка сюме, бурханы - в } \\
\text { единичных случаях, в нескольких } \\
\text { текстах - ламы, хурулы, названия } \\
\text { служителей, «Дорджи джодва». } \\
\text { Следы добуддийских культов от- } \\
\text { сутствуют }\end{array}$ & $\begin{array}{l}\text { Присутствуют в разных формах, как } \\
\text { буддийские, так и добуддийские }\end{array}$ \\
\hline $\begin{array}{l}\text { Описание богатырского } \\
\text { лечения }\end{array}$ & \begin{tabular}{|lll} 
Сложный & мотив \\
лекарства
\end{tabular} & $\begin{array}{l}\text { Описание очень кратко: богатырь имеет } \\
\text { снадобье при себе }\end{array}$ \\
\hline Победа героя над врагом & $\begin{array}{|lll|}\begin{array}{l}\text { Любыми } \\
\text { хитростью }\end{array} & \text { средствами, } \\
\end{array}$ & $\begin{array}{l}\text { Богатырским оружием и собственной } \\
\text { силой }\end{array}$ \\
\hline Финальный пир & \begin{tabular}{|l|}
$\begin{array}{l}\text { Присутствует нерегулярно. Как } \\
\text { правило, финал повествования }\end{array}$ \\
\end{tabular} & $\begin{array}{l}\text { По существу обязателен. Постоянный } \\
\text { эпизод, финал отдельных песен }\end{array}$ \\
\hline $\begin{array}{l}\text { Социальные мотивы в сцене } \\
\text { пира }\end{array}$ & Отмечаются как единичный случай & $\begin{array}{l}\text { Заложены однажды стандартом, воспро- } \\
\text { изводящим реальность императорского } \\
\text { двора времен Цин }\end{array}$ \\
\hline $\begin{array}{l}\text { Включение исполнителя в } \\
\text { повествование («И я там } \\
\text { был»). }\end{array}$ & Встречается довольно редко & $\begin{array}{l}\text { Невозможно. В песнях «Джангара этот } \\
\text { эпос исполняет один из героев. }\end{array}$ \\
\hline
\end{tabular}

Как мы отмечали, исследователи, обсуждая проблемы эпоса и богатырской сказки, по большей части отмечали сходства героев, мотивов, формул и т. п. Однако различия между этими фольклорными формами, причем такие различия, которые касаются фундаментальных свойств эпоса и богатырской сказки и не характерны для отдельных образцов, видны весьма выразительно.

В отношениях между героическим эпосом и богатырской сказкой действительно имеется много общего, и констатация этого факта в целом или множества мотивов и деталей вряд ли удивит кого-нибудь. Для теории и для практики описания образцов отдельных жанров гораздо важнее не общность, не сходства, а различия, причем жанроопределяющие различия - те элементы, которые будут характерны преимущественно для эпоса или преимущественно для богатырской сказки.

Богатырская сказка имеет еще одну особенность - форма богатырской сказки, видимо, более подвижна, более вариативна, нежели эпическая форма. В частности, для сказки пропуск функций или мотивов характерен в большей мере, чем для эпоса. Указанные свойства - это следствие большей динамичности повествования в богатырской сказке за счет минимального использования средств эпической поэтики почти полного отсутствия амплификаций описания.

В калмыцкой фольклорной традиции открывается возможность сравнивать собственно эпические и сказочные версии одних и тех же произведений - к ним относятся две песни «Джангара» в форме богатырской сказки [Калмыцкие богатырские сказки 2017: 221 и сл., 449 и сл.] и два рассказа о Гэсэре [Калмыцкие богатырские сказки 2017: 177 и сл., 185 и сл.]. Эти тексты явно вторичны по отношению к эпическим формам «Джангара» и «Гэсэра» и по этой причине могут служить только примерами поздних трансформаций эпоса.

Подводя итоги, надо признать, что глубокие различия между эпосом и богатырской сказкой действительно существуют, и эти формы представляют разные жанры. 
Сходство между образцами этих форм обусловлено близостью сюжета, характером персонажей и их основными функциями в повествовании, а также взаимозависимостью поэтики, поскольку богатырская сказка при наличии условий обогащается выразительными средствами эпоса. Вместе с этим богатырские сказки - отчасти из-за специфики собственных сюжетов и благоприобретенных за счет эпоса художественных особенностей - занимают особое место в ряду волшебных сказок и справедливо выделяются в отдельную жанровую группу, подобно сказкам о животных и бытовым сказкам.

\section{ЛИТЕРАТУРА / REFERENCES}

Алтайские народные сказки 2002 - Алтайские народные сказки / сост. Т. М. Садалова. Новосибирск: Наука, 2002. 455 с. [Altayskie narodnye skazki [Altai folk tales]. T. M. Sadalova (comp.). Novosibirsk: Nauka, 2002. 455 p. (In Rus.)]

Бардаханова 2011 - Бардаханова С. С. Сказки в системе жанров бурятского фольклора // Филологические науки. Вопросы теории и практики. Тамбов: Грамота, 2011. № 4 (11). C. 18-22. [Bardakhanova S. S. Fairy tales in the system of genres of Buryat folklore. Filologicheskie nauki. Voprosy teorii $i$ praktiki. Tambov: Gramota, 2011. No. 4 (11). Pp. 18-22. (In Rus.)]

Баркова 2003 - Баркова А. Л. Функции «младших героев» в эпическом сюжете: дис. ... канд. филол. наук. М., 2003. 131 с. [Barkova A. L. Funktsii "mladshikh geroev" v ehpicheskom syuzhete [Functions of "younger heroes' in the epic story]. A PhD thesis. Moscow, 2003. 131 p. (In Rus.)]

Батмаев 1993 - Батмаев М. М. Калмыки в XVII-XIX вв. События, люди, быт. Элиста: Калм. кн. изд-во, 1993. 381 с. [Batmaev M. M. Kalmyki v XVII-XIX vv. Sobytiya, lyudi, byt [Kalmyks in the $17^{\text {th }}-19^{\text {th }}$ centuries: events, people, everyday life]. Elista: Kalm. Book Publ., 1993. 381 p. (In Rus.)]

Батыров 2015 - Батыров В. В. Левират у калмыков в XIX в. // Вестник Калмыцкого института гуманитарных исследований РАН. 2015. № 4. C. 66-71. [Batyrov V. V. Levirat among the Kalmyks in the $19^{\text {th }}$ century. Vestnik Kalmytskogo instituta gumanitarnykh issledovaniy RAN. 2015. No. 4. Pp. 66-71. (In Rus.)]

Борджанова 1980 - Борджанова Т. Г. О взаимосвязи эпоса «Джангар» и богатырских сказок // «Джангар» и проблемы эпическо- го творчества тюрко-монгольских народов: Мат-лы Всесоюзной науч. конф. (г. Элиста, 17-19 мая 1978 г.). М.: Наука, 1980. С. 214219. [Bordzhanova T. G. On the relationship between the Jangar epic and heroic tales. Dzhangar" i problemy ehpicheskogo tvorchestva tyurko-mongol'skikh narodov. [Jangar and problems of epic creativity of the Turkic-Mongolian peoples]. Proc. of the All-Union scientific conf.]. Moscow: Nauka, 1980. Pp. 214-219. (In Rus.)]

Борджанова 1987 - Борджанова Т. Г. Калмыцкая богатырская сказка // Актуальные проблемы народов Северного Кавказа и Дагестана: тезисы докладов и сообщений регион. науч. конф. (г. Махачкала, 18-20 ноября 1987 г.). Махачкала, 1987. С. 39-40. [Bordzhanova T. G. The Kalmyk heroic fairy tale. Aktual'nye problemy narodov Severnogo Kavkaza i Dagestana [Topical problems of the peoples of the North Caucasus and Dagestan]. Theses of the regional scientif. conf. (Makhachkala, November 18-20, 1987). Makhachkala, 1987. Pp. 39-40. (In Rus.)]

Бурыкин 1990 - Бурыкин А. А. Фольклорно-повествовательные жанры как типы текстов // Семантические и коммуникативные категории текста (типология и функционирование). Тезисы докладов Всесоюзной науч. конф. Ереван: изд-во Ерев. гос. ун-та, 1990. C. 29-30. [Burykin A. A. Folklore-narrative genres as types of texts. Semanticheskie $i$ kommunikativnye kategorii teksta (tipologiya $i$ funktsionirovanie) [Semantic and communicative categories of text (typology and functioning)]. Theses of the All-Union scientif. conf.]. Erevan: Erevan State Univ., 1990. Pp. 29-30. (In Rus.)]

Бурыкин 2004 - Бурыкин А. А. Замечания к композиции некоторых песен «Джангара»: смена «точки зрения» и проблема происхождения различий в экспозиции песен со сходными сюжетами // «Джангар» в евразийском культурном пространстве. Мат-лы междунар. науч. конф. (г. Элиста, 27 сентября - 2 октября 2004 г.). Элиста, 2004. C. 43-47. [Burykin A. A. Notes on the structure of some Jangar songs: changes of 'viewpoints' and the problem of causes resulting in different expositions of songs with similar plots. "Dzhangar» v evraziyskom kul'turnom prostranstve [The Jangar in Eurasia's cultural environment]. Conf. proc. (Elista, 27 Sept. 2 Oct. 2004). Elista, 2004. Pp. 43-47. (In Rus.)] Бурыкин 2014 - Бурыкин А. А. Описание богатырского пира в «Джангаре» и его возмож- 
ные реальные источники (характеристики церемоний пиров китайских императоров начала XIX в.) // Монголоведение: сб. науч. тр. Вып. 7. Элиста: КИГИ РАН, 2014. С. 7080. [Burykin A. A. Description of the heroic feast in the Jangar and its possible real sources (characteristics of Chinese emperors' cereminial feasts in the early $19^{\text {th }} \mathrm{c}$.). Mongolovedenie [Mongol Studies]. Is. 7. Elista: Kalmyk Humanities Research Institute of RAS, 2014. Pp. 70-80. (In Rus.)]

Бурыкин 2016 - Бурыкин А. А. «Джангар» и современные проблемы исторической поэтики эпических фольклорных форм // «Джангар» и эпические традиции тюрко-монгольских народов: проблемы сохранения и исследования. Мат-лы III Междунар. конф. (г. Элиста, 15-16 сентября 2016 г.). Элиста: КИГИ PAH, 2016. C. 27-32. [Burykin A. A. The Jangar and modern challenges of historical poetics of epic folklore forms. "Dzhangar" $i$ ehpicheskie traditsii tyurko-mongol'skikh narodov: problemy sokhraneniya $i$ issledovaniya [The Jangar and the Turco-Mongolian epic traditions: challenges of preservation and research. Conf. proc. (Elista, 15-16 Sept. 2016)]. Elista: Kalmyk Humanities Research Institute of RAS, 2016. Pp. 27-32. (In Rus.)]

Бурыкин 2017 - Бурыкин А. А. Мифологические экспозиции эпических сказаний эвенков и эвенов и их роль для изучения тунгусской космогонической мифологии и для характеристики этнических и локальных традиций // Вестник Северо-Восточного федерального университета им. М. К. Аммосова. Серия «Эпосоведение». 2017. № 2. C. 17-26. [Burykin A. A. Mythological expositions of epic legends of the Evenki and Evens and its role for studying the Tunguscosmogonic mythology and for the characteristics of ethnic and local traditions. Vestnik Severo-Vostochnogo federal'nogo universiteta imeni M. K. Ammosova. 2017. No. 2. Pp. 17-26. (In Rus.)]

Бурятские волшебные сказки 1993 - Бурятские волшебные сказки / сост. Е. В. Баранникова, С. С. Бардаханова. Новосибирск: Наука, 1993. 341 c. [Buryatskie volshebnye skazki [Buryat magic fairy tales]. E. V. Barannikova, S. S. Bardakhanova (comp.). Novosibirsk: Nauka, 1993. 341 p. (In Rus.)]

Бухуров 2015 - Бухуров М. Ф. Адыгская богатырская сказка. Нальчик: издат. отдел Кабардино-Балкарского института гуманитарных исследований (КБИГИ), 2015. 160 с. [Bukhurov M. F. Adygskaya bogatyrskaya skazka [The Adyghe heroic tale]. Nalchik:
Kabardino-Balkarian Humanities Research Institute, 2015. 160 p. (In Rus.)]

Варламов, Варламова 2011 - Варламов А. Н., Варламова Г. И. Эпос и богатырская сказка в эпической традиции восточных эвенков // Филологические науки. Вопросы теории и практики. 2011. № 4. С. 38-40. [Varlamov A. N., Varlamova G. I. The epic and heroic fairy tale in the epic tradition of the Eastern Evenks. Filologicheskie nauki. Voprosy teorii i praktiki. 2011. No. 4. Pp. 38-40. (In Rus.)]

Восточнославянский фольклор 1993 - Восточнославянский фольклор. Словарь научной и народной терминологии. Минск: Наука и техника, 1993. 478 с. [Vostochnoslavjanskiy fol'klor. Slovar' nauchnoy i narodnoy terminologii [East Slavic folklore. Dictionary of scientific and folk terminology]. Minsk: Nauka \& Tekhnika, 1993. 478 p. (In Rus.)]

Дампилова 2008 - Дампилова Л. С. Феномен сказителя-шамана в тюрко-монгольской фольклористике // ICANAS-38. Ankara, 2008. Том I: Религия. C. 87-107. [Dampilova L. S. A phenomenon of the shaman-narrator in Turco-Mongolian folklore]. ICANAS-38. Ankara, 2008. Vol. I: Religion. Pp. 87-107. (In Rus.)]

Дьяконова 1990 - Дьяконова Ю. Н. Якутская сказка (Русско-якутские взаимосвязи). Л.: Наука, 1990. 184 c. [Diakonova Yu. N. Yakutskaya skazka (Russko-yakutskie vzaimosvyazi) [The Yakut fairy tale (Russian-Yakut interconnections)]. Leningrad: Nauka, 1990. 184 p. (In Rus.)]

Жирмунский 1974 - Жирмунский В. М. Тюркский героический эпос. М.: Наука, 1974. 727 c. [Zhirmunsky V. M. Tyurkskiy geroicheskiy epos [The Turkic heroic epic]. Moscow: Nauka, 1974. 727 p. (In Rus.)]

Закирова 2017 - Закирова И. Г. Татарская богатырская сказка // Филологические науки. Вопросы теории и практики. 2017. № 9(75): в 2-х ч. Ч. 2. С. 31-34. [Zakirova I. G. The Tatar heroic fairy tale. Filologicheskie nauki. Voprosy teorii i praktiki. 2017. No. 9 (75): in 2 parts. Part 2. Pp. 31-34. (In Rus.)]

Калмыцкие богатырские сказки 2017 - Калмыцкие богатырские сказки / Подготовка текстов, переложение калмыцких текстов, перевод, примечания, комментарии, указатели, словарь Б. Б. Манджиевой, Т. А. Михалевой, Ц. Б. Селеевой. Элиста: КалмНЦ РАН, 2017. 563 c. [Kalmytskie bogatyrskie skazki [The Kalmyk heroic tales]. B. B. Mandzhieva, T. A. Mikhaleva, Ts. B. Seleeva (comp., trasl., edit., etc.). Elista: Kalmyk Scientific Center of 
RAS. 2017. 563 p. (In Rus. and Kalm.)]

Калмыцкие народные сказки 1978 - Калмыцкие народные сказки. Элиста: Калм. кн. издво, 1978. 146 c. [Kalmytskie narodnye skazki [Kalmyk folk tales]. Elista: Kalm. Book Publ., 1978, 146 p. (In Rus.)]

Кербелите 1995 - Кербелите Б. К секретам строения сказки // Живая старина. 1995. № 3. C. 25-26. [Kerbelite B. Secrets of the fairy tale structure revisited. Zhivaya starina. 1995. No. 3. Pp. 25-26. (In Rus.)]

Кичиков $1992-$ Кичиков А. Ш. Героический эпос «Джангар». Сравнительно-типологическое исследование памятника. М.: Наука, 1992. 320 c. [Kichikov A. Sh. Geroicheskiy epos «Dzhangar». Sravnitel'no-tipologicheskoe issledovanie pamyatnika [The heroic epic of Jangar. A comparative-typological study of the monument]. Moscow: Nauka, 1992. 320 p. (In Rus.)]

Лорд 1994 - Лорд А. Б. Сказитель. М.: Вост. лит., 1994. 268 с. [Lord А. В. Skazitel' [The Taleteller]. Moscow: Vost. Lit., 1994. 268 p. (In Rus.)]

Манджиева 2001 - Манджиева Б. Б. Эпический пролог «Джангара» как константа // Вестник Института. Элиста: КИГИ РАН, 2001. С. 7173. [Mandzhieva B. B. The epic prologue of the Jangar as a constant]. Vestnik of Institute. Elista: KIH RAS, 2001. Pp. 71-73. (In Rus.)]

Манджиева 2004 - Манджиева Б. Б. Пролог в поэтико-стилевой традиции «Джангара» (Малодербетовская версия 1862 г.) // Автореф. дис. ... канд. филол. наук. М., 2004. 21 c. [Mandzhieva B. B. Prolog v poetiko-stilevoy traditsii "Dzhangara" (Maloderbetovskaya versiya 1862 g.): Avtoref. dis. ... kand. filol. nauk [The prologue in the poetic-stylistic tradition of the Jangar (Maloderbetovsky version of 1862)]. A PhD thesis absract. Moscow, 2004. 21 p. (In Rus.)]

Манджиева 2015a - Манджиева Б. Б. Герой богатырской сказки и героического эпоса «Джангар» как защитник отечества // «Вклад регионов и народов юга России в победу в Великой Отечественной войне 1941-1945 гг.». Мат-лы Всерос. науч.-практ. конф. Элиста: КалмГУ, 2015. С. 278-281. [Mandzhieva B. B. A hero of the heroic fairy tale and heroic epic of Jangar as the defender of the Fatherland. Vklad regionov $i$ narodov yuga Rossii v pobedu v Velikoy Otechestvennoy voyne 1941-1945 gg. [Regions and peoples of Southern Russia: contribution to the Victory in the Great Patriotic War of 1941-1945]. Conf. proc. Elista: Kalmyk State Univ., 2015.
Pp. 278-281. (In Rus.)]

Манджиева 20156 - Манджиева Б. Б. К вопросу изучения калмыцких богатырских сказок // XLIV Междунар. филолог. научн. конф. Санкт-Петербург, 10-15 марта 2015 г.: Тезисы докладов. СПб.: Филологический факультет СПбГУ, 2015. С. 741-742. [Mandzhieva B. B. Studies of Kalmyk heroic fairy tales revisited. XLIV Mezhdunarodnaya filolog. nauchn. konf. Sankt-Peterburg, 10-15 marta $2015 \mathrm{~g}$. [44 ${ }^{\text {th }}$ Internat. philolog. scientific. conf. (St. Petersburg, 10-15 March 2015]. Theses abs. St. Petersburg: St. Petersburg State Univ., 2015. Pp. 741-742. (In Rus.)]

Манджиева 2015в - Манджиева Б. Б. К истории изучения и публикации калмыцких богатырских сказок [электронный ресурс] // Современные проблемы науки и образования. 2015. № 1 (2). URL: https://science-education.ru/pdf/2015/1-2/177.pdf (дата обращения: 10.07.2018). [Mandzhieva B. B. Kalmyk heroic tales: history of research and publication revisited. Sovremennye problemy nauki i obrazovaniya. 2015. No. 1 (2). An Internet resource: see hyperlink above (accessed: 10 July 2018). (In Rus.)]

Манджиева 2015г - Манджиева Б. Б. Конь героя в калмыцкой богатырской сказке и в героическом эпосе «Джангар» [электронный pecypc] // Современные проблемы науки и образования. 2015. № 1 (1) URL: https:// science-education.ru/ru/article/view?id=18302 (дата обращения: 10.07.2018). [Mandzhieva B. B. The hero's horse in Kalmyk heroic fairy tales and in the Jangar epic. Sovremennye problemy nauki i obrazovaniya. 2015. No. 1 (1). An Internet resource: see hyperlink above (accessed: 10 July 2018). (In Rus.)]

Манджиева 2015д - Манджиева Б. Б. Поэтика и стиль калмыцкой богатырской сказки. Рец. на: Сарангов В. Т. Поэтика и стиль калмыцкой богатырской сказки. Элиста: изд-во Калм. ун-та, 2015. 104 с. // Новые исследования Тувы. 2015. № 3. С. 156-161. [Mandzhieva B. B. Poetics and style of the Kalmyk heroic fairy tale. Book review: Sarangov V. T. Poetics and style of the Kalmyk heroic fairy tale. Elista: Kalm. State Univ., 2015. 104 p. Novye issledovaniya Tuvy. 2015. No. 3. Pp. 156-161. (In Rus.)]

Манджиева 2016а - Манджиева Б. Б. К проблеме изучения мотивов калмыцкой богатырской сказки и героического эпоса «Джангар» // Вестник Северо-Восточного федерального университета имени М. К. Аммосова. Серия Эпосоведение. 2016. № 1 (01). 
C. 44-49. [Mandzhieva B. B. Studying the motifs of Kalmyk heroic fairy tales and the Jangar epic: challenges revisited. Vestnik SeveroVostochnogo federal'nogo universiteta imeni M. K. Ammosova. 2016. No. 1 (01). Pp. 44-49. (In Rus.)]

Манджиева $2016 б$ - Манджиева Б. Б. Традиционные формулы калмыцкой богатырской сказки и героического эпоса «Джангар» // Филологические науки. Вопросы теории и практики. 2016. № 12 (66): в 4-х ч. Ч. 3. С. 39-42. [Mandzhieva B. B. Kalmyk heroic tales and the epic of Jangar: traditional formulas. Filologicheskie nauki. Voprosy teorii i praktiki. 2016. No. 12 (66): in 4 parts. Part 3. Pp. 39-42. (In Rus.)]

Манджиева 2017а - Манджиева Б. Б. К вопросу изучения инициальных и финальных формул калмыцкой богатырской сказки // Известия Дагестанского государственного педагогического университета. Общественные и гуманитарные науки. 2017. № 11(3). C. 66-71. [Mandzhieva B. B. Studies of initial and final formulas of the Kalmyk heroic fairy tale revisited. Izvestija Dagestanskogo gosudarstvennogo pedagogicheskogo universiteta. Obshhestvennye i gumanitarnye nauki. 2017. No. 11 (3). Pp. 66-71. (In Rus.)]

Манджиева 20176 - Манджиева Б. Б. К вопросу изучения калмыцкой богатырской сказки «Хар һалзн мөртә Хадр Хар Авһин Хан Сөнәк» (Хадыр Хара Авгин Хан Сенаки на вороном с лысиной коне) сказителя Санджи Бутаева // Вестник Калмыцкого института гуманитарных исследований РАН. 2017. № 6. C. 150-159. [Mandzhieva B. B. 'Khar halzn mörtä Khadyr Khar Avhin Khan Sönäk’ (Khadyr Khara Avgin Khan Senaki who owns a bald-headed black horse) recorded from the taleteller Sandzhi Butaev: studies revisited]. Vestnik Kalmytskogo instituta gumanitarnykh issledovanij RAN. 2017. No. 6. Pp. 150-159. (In Rus.)]

Манджиева 2017в - Манджиева Б. Б. К проблеме составления Свода калмыцкого фольклора // Языки и фольклор коренных народов Сибири. 2017. № 1 (32). С. 82-89. [Mandzhieva B. B. Compiling the Kalmyk Folklore Corpus: the challenge revisited. Yazyki i fol'klor korennykh narodov Sibiri. 2017. No. 1 (32). Pp. 82-89. (In Rus.)]

Медноволосая девушка 1964 - Медноволосая девушка. М.: Наука, 1964. 272 с. [Mednovolosaya devushka [The copper-haired girl]. Moscow: Nauka, 1964. 272 p. (In Rus.)]

Мелетинский 2004 - Мелетинский Е. М. Поэти- ка мифа. М.: ГРВЛ, 2004. 407 с. [Meletinsky E. M. Poetika mifa [Poetics of myth]. Moscow: Vost. Lit., 2004. 407 p. (In Rus.)]

Меняев 2016 - Меняев Б. В. О жанровой классификации фольклора ойратов Китая (по материалам журнала «Хан Тенгер») [электронный ресурс] // Современные научные исследования и инновации. 2016. № 11. // URL: http://web.snauka.ru/issues/2016/11/74897 (дата обращения: 14.08.2018). [Menyaev B. V. Folklore of China's Oirats: revisiting the genre classification (a case study of materials published by Khan Tenger journal). Sovremennye nauchnye issledovaniya i innovatsii. 2016. No. 11. An Internet resource: see hyperlink above (accessed: 14 August 2018). (In Rus.)]

Мутляева 1978 - Мутляева Б. Э. Мотив чудесного рождения героя в тюрко-монгольском героическом и сказочном эпосе // Типологические и художественные особенности «Джангара». Элиста: Калм. кн. изд-во, 1978. C. 51-62. [Mutlyaeva B. Eh. A motif of the hero's miraculous birth in the Turco-Mongolian heroic and magic epic. Tipologicheskie $i \mathrm{khu}$ dozhestvennye osobennosti "Dzhangara” [Typological and artistic features of the Jangar]. Elista: Kalm. Book Publ., 1978. Pp. 51-62. (In Rus.)]

Мутляева 1982 - Мутляева Б. Э. Мотив чудесного рождения героя в сказочном эпосе монгольских народов и калмыцком эпосе «Джангар» // Эпическая поэзия монгольских народов. (Исследования по эпосу). Элиста: Калм. кн. изд-во, 1982. С. 43-49. [Mutlyaeva B. E. A motif of the hero's miraculous birth in the Mongolian fairy-tale epic and the Kalmyk epic of Jangar. Ehpicheskaya poezija mongol'skikh narodov [Epic poetry of the Mongolic peoples]. Elista: Kalm. Book Publ., 1982. Pp. 43-49. (In Rus.)]

Неклюдов 1975 - Неклюдов С. Ю. Богатырская сказка. Тематический диапазон и сюжетная структура // Проблемы фольклора. М.: Наука, 1975. С. 82-88. [Neklyudov S. Yu. The heroic fairy tale: thematic range and plot structure. Problemy fol'klora. Moscow: Nauka, 1975. Pp. 82-88. (In Rus.)]

Неклюдов 1984 - Неклюдов С. Ю. Героический эпос монгольских народов. М.: Наука, ГРВЛ, 1984. 316 с. [Neklyudov S. Yu. Geroicheskiy epos mongol'skikh narodov [The heroic epic of the Mongols]. Moscow: Nauka, Vost. Lit., 1984. 316 p. (In Rus.)]

Неклюдов 1995 - Неклюдов С. Ю. В. Я. Пропп и «Морфология сказки» // Живая старина. 1995. № 3. C. 29-30. [Neklyudov S. Yu. V. Ya. 
Propp $i$ «Morfologiya skazki» [V. Ya. Propp and (his) 'Morphology of the fairy tale'. Zhivaya starina. 1995. No. 3. Pp. 29-30. (In Rus.)]

Новик 1984 - Новик E. C. Обряд и фольклор в сибирском шаманизме. М.: Наука, ГРВЛ, 1984. 304 c. [Novik E. S. Obryad i fol'klor v sibirskom shamanizme [The ritual and folklore in Siberian shamanism]. Moscow: Nauka, Vost. Lit., 1984. 304 p. (In Rus.)]

Овчинников 1908 - Овчинников М. Сордохайбогатырь. Якутская богатырская сказка // Извъстія Восточно-Сибирскаго Отдьла Императорскаго Русскаго Географическаго Общества. Т. XXXV. 1904 г. № 2. Иркутск, 1908. C. 1-8. [Ovchinnikov M. Sordokhai the hero. A Yakut heroic fairy tale. Izvestiya Vostochno-Sibirskago Otdela Imperatorskago Russkago Geograficheskago Obshhestva. Vol. XXXV. 1904. No. 2. Irkutsk, 1908. Pp. 1-8. (In Rus.)]

Пропп 1928 - Пропn В. Я. Морфология сказки. Л.: Academia, 1928. 152 c. [Propp V. Ya. Morfologiya skazki [Morphology of the fairy tale]. Leningrad: Academia, 1928. 152 p. (In Rus.)]

Путилов 1997 - Путилов Б. Н. Эпическое сказительство: Типологи и этническая специфика. М.: Вост. лит., 1997. 295 с. [Putilov B. N. Epicheskoe skazitel'stvo: Tipologi i ehtnicheskaya spetsifika [Epic taletelling (tradition): typologies and ethnic specifics]. Moscow: Vost. Lit., 1997. 295 p. (In Rus.)]

Райхл 2008 - Райхл К. Тюркский эпос: традиции, формы, поэтическая структура. М.: Вост. лит., 2008. 383 с. [Reichl K. Tyurkskiy epos: traditsii, formy, poeticheskaya struktura [The Turkic epic: traditions, forms, poetic structure]. Moscow: Vost. Lit., 2008. 383 p. (In Rus.)]

Рафаева 1995 - Рафаева A. B. От «морфологии сказки» к морфологии повествования // Живая старина. 1995. № 3. С. 31-32. [Rafaeva A. V. From the 'morphology of the fairy tale' to that of the narrative. Zhivaya starina. 1995. No. 3. Pp. 31-32. (In Rus.)]

Рафаева 1998 - Рафаева A. B. Методы В. Я. Проппа в современной науке // Пропп В. Я. Морфология <волшебной> сказки. Исторические корни волшебной сказки. (Собрание трудов В. Я. Проппа) / комментарии Е. М. Мелетинского, А. В. Рафаевой; составление, научная редакция, текстологический комментарий И. В. Пешкова. М.: Лабиринт, 1998. С. 467-485. [Rafaeva A. V. V. Propp's methods in modern science. Propp V. Ya. Morfologiya <volshebnoy> skazki. Istoricheskie korni volshebnoy skazki [Mor- phology of the fairy tale. Historical roots of tha magic tale. Collected works]. E. M. Meletinsky, A. V. Rafayeva (comment.). I. V. Peshkov (comp., ed., etc.)]. Moscow: Labirint, 1998. Pp. 467-485. (In Rus.)]

Рафаева 2007 - Рафаева А. В. Как изменяются сказки: к методу исследования // Проблемы лингвистической прогностики: сб. науч. тр. / под ред. А. А. Кретова. Воронеж: Наука-Юнипресс, 2007. С. 111-130. [Rafaeva A. V. How tales change: the research method revisited. Problemy lingvisticheskoy prognostiki [Problems of linguistic prognostics]. Coll. papers. A. A. Kretov (ed.)]. Voronezh: NaukaYunipress, 2007. Pp. 111-130. (In Rus.)]

Сандаловый ларец 2003 - Сандаловый ларец / сост. Т. Г. Басангова. Элиста: Калм. кн. изд-во, 2003. 239 с. [Sandalovyy larets [The Sandalwood Chest]. T. G. Basangova (comp.). Elista: Kalm. Book Publ., 2003. 239 p. (In Rus.)]

Сарангов 1989 - Сарангов В. Т. О калмыцких богатырских сказках // Владимирцовские чтения. Тез. докл. и сообщ. 2-й Всесоюз. конф. монголоведов. М.: ИВ АН СССР, 1989. C. 145-146. [Sarangov V. T. About Kalmyk heroic tales. Vladimirtsovskie chteniya [The Vladimirtsov readings]. Conf. theses. Moscow: Inst. of Oriental Studies of USSR Acad. of Sc., 1989. Pp. 145-146. (In Rus.)]

Сарангов 1990а - Сарангов В. Т. Калмыцкие волшебно-героические сказки: автореф. дис. ... канд. филол. наук. М., 1990. 26 с. [Sarangov V. T. Kalmytskie volshebno-geroicheskie skazki: avtoref. dis. ... kand. filol. nauk [Kalmyk magic and heroic tales]. A PhD thesis abtract. Moscow, 1990. 26 p. (In Rus.)]

Сарангов $1990 б$ - Сарангов В. Т. Поэтическая структура калмыцких богатырских сказок и их соотношение с эпическим жанром // «Джангар» и проблемы эпического творчества. Тез. докл. и сообщ. Междунар. науч. конф. (г. Элиста, 22-24 авг. 1990 г.). Элиста: Калм. кн. изд-во, 1990. С. 55-57. [Sarangov V. T. The poetic structure of Kalmyk heroic fairy tales and their correlation with the epic genre. "Dzhangar" i problemy ehpicheskogo tvorchestva. [The Jangar and problems of epic creativity]. Conf. theses (Elista, 22-24 Aug. 1990). Elista: Kalm. Book Publ., 1990. Pp. 5557. (In Rus.)]

Сарангов 1997 - Сарангов В. Т. Калмыцкие сказки о богатырях как разрушенные формы героических сказаний // VII Междунар. конгресс монголоведов. Улан-Батор, авг. 1997 г. Докл. росс. делегации. М.: Наука, 
1997. C. 158-159. [Sarangov V. T. Kalmyk heroic tales as somewhat destroyed forms of heroic legends. VII Mezhdunar. kongress mongolovedov. Ulan-Bator, avg. 1997 g. Dokl. ross. delegatsii $\left[7^{\text {th }}\right.$ Internat. Congress of Mongolologists]. Reports of Russian scholars (Ulaanbaatar, Aug. 1997). Moscow: Nauka, 1997. Pp. 158-159. (In Rus.)]

Сарангов 2015 - Сарангов В. Т. Поэтика и стиль калмыцкой богатырской сказки. Элиста: Изд-во Калм. ун-та, 2015. 104 с. [Sarangov V. T. Poetika i stil' kalmytskoy bogatyrskoy skazki [Poetics and style of the Kalmyk heroic tale]. Elista: Kalm. State Univ., 2015. 104 p. (In Rus.)]

Селеева 2004 - Селеева Ц. Б. Финальные формулы как отражение прагматики эпического текста // «Джангар» в евразийском пространстве: материалы междунар. науч. конф. / отв. ред. Г. М. Борликов. Элиста, 2004. C. 288-291. [Seleeva Ts. B. Final formulas as a reflection of the pragmatics of the epic text. "Dzhangar" v evraziyskom prostranstve: materialy mezhdunar. Conf. proc. G. Borlikov (ed.). Elista: Kalm. State Univ., 2004. Pp. 288 291. (In Rus.)]

Селеева 2006 - Селеева Ц. Б. К вопросу о тематической составляющей песен синьцзянойратской версии эпоса «Джангар» // Научная мысль Кавказа. Спецвыпуск № 3. 2006. C. 142-143. [Seleeva Ts. B. Songs of the Xinjiang-Oirat version of the Jangar epic: revisiting the thematic component. Nauchnaya mysl' $\mathrm{Ka}$ vkaza. Spec. is. 3. 2006. Pp. 142-143. (In Rus.)]

Селеева 2008 - Селеева Ц. Б. Мотив пира в структуре эпического сюжета (на примере синьцзян-ойратской и калмыцкой версий эпоса «Джангар») // Вестник Калмыцкого института гуманитарных исследований PAH. 2008. № 3. C. 52-54. [Seleeva Ts. B. A structure of the epic plot: the motif of a feast (a case study of the Xinjiang Oirat and Kalmyk versions of the Jangar epic)]. Vestnik Kalmytskogo instituta gumanitarnykh issledovanij RAN. 2008. No. 3. Pp. 52-54. (In Rus.)]

Селеева 2012 - Селеева Ц. Б. Об указателе эпических тем (из опыта составления) // Вестник Калмыцкого института гуманитарных исследований РАН. 2012. № 4. С. 122-126. [Seleeva Ts. B. About the Index of epic themes (excerpts from the experience of compilation). Vestnik Kalmytskogo instituta gumanitarnykh issledovanij RAN. 2012. No. 4. Pp. 122-126. (In Rus.)]

Селеева 2013 - Селеева Ц. Б. Указатель тем калмыцкой и синьцзян-ойратской версий эпоса «Джангар». Элиста: КИГИ РАН, 2013.
276 c. [Seleeva Ts. B. The Index of themes to the Kalmyk and Xinjiang Oirat versions of the Jangar epic]. Elista: Kalmyk Humanities Research Institute of RAS, 2013. 276 p. (In Rus.)]

Селеева 2015 - Селеева Ц. Б. Специфическое и универсальное в образе героя калмыцкой богатырской сказки и эпоса «Джангар» // Вестник Калмыцкого института гуманитарных исследований РАН. 2015. № 2. С. 151155. [Seleeva Ts. B. Kalmyk heroic fairy tales and the Jangar epic: specific and universal features in the image of a hero]. Vestnik Kalmytskogo instituta gumanitarnykh issledovanij RAN. 2015. No. 2. Pp. 151-155. (In Rus.)]

Селеева 2016 - Селеева Ц. Б. Об архаических рудиментах богатырской сказки в эпосе «Джангар» // Вестник Северо-Восточного федерального университета имени М. К. Аммосова. Серия «Эпосоведение». 2016. № 2(02). C. 74-79. [Seleeva Ts. B. About archaic rudiments of the heroic fairy tale in the Jangar epic. Vestnik Severo-Vostochnogo federal'nogo universiteta imeni M. K. Ammosova: Seriya Eposovedenie. 2016. No. 2 (02). Pp. 74-79. (In Rus.)]

Селеева 2017 - Селеева Ц. Б. Тематическая структура эпоса «Джангар»: Калмыцкая версия Ээлян Овла и ее синьцзян-ойратские соответствия. Дис. ... канд. филол. наук [Seleeva Ts. B. Tematicheskaya struktura eposa "Dzhangar": Kalmytskaya versiya Eelyan Ovla $i$ ee sin'tszyan-oyratskie sootvetstviya. Dis... kand. filol. nauk [A thematic structure of the Jangar epic: the Kalmyk version by Eelyan Ovla and Xinjiang Oirat equivalents]. A PhD thesis. Moscow, 2017. 489 p. (In Rus.)]

Сказки и предания 1994 - Сказки и предания алтайских тувинцев / сост. Э. Таубе. М.: Вост. лит., 1994. 382 с. [Skazki i predaniya altayskikh tuvintsev [Tales and legends of the Altai Tuvinians]. E. Taube (comp.). Moscow: Vost. Lit., 1994. 382 p. (In Rus.)]

Сергеева 1968 - Сказочник Кивагмэ / сост. К. С. Сергеева. Магадан: Магаданск. кн. изд-во, 1968. 160 с. [Skazochnik Kivagmeh [Storyteller Kiwagme]. K. S. Sergeeva (comp.). Magadan: Magadan publishing house, 1968. 160 p.]

Смирнов 2008 - Смирнов Ю. И. Якутские сказки // Якутские народные сказки. Новосибирск: Наука, 2008. C. 11-36. [Smirnov Yu. I. Yakut fairy tales. Yakutskie narodnye skazki [Yakut folk tales]. Novosibirsk: Nauka, 2008. Pp. 11-36. (In Rus.)]

Структура волшебной сказки 2001 - Структу- 
ра волшебной сказки / отв. ред. С. Ю. Неклюдов. М.: РГГУ, 2001. 234 с. [Struktura volshebnoy skazki [Structure of the magic tale]. S. Neklyudov (ed.). Moscow: Russian State Univ. for the Humanities, 2001. 234 p. (In Rus.)]

Структурализм 1975 - Структурализм: за и против. М.: Прогресс, 1975. 469 с. [Strukturalizm: za i protiv [Structuralism: pros and cons]. Moscow: Progress, 1975. 469 p. (In Rus.)]

Тувинские народные сказки 1971 - Тувинские народные сказки. М.: ГРВЛ, 1971. 208 с. [Tuvinskie narodnye skazki [Tuvan folk tales]. Moscow: Vost. Lit., 1971. 208 p. (In Rus.)]

Урманче 2015 - Урманче Ф. И. Тюркский героический эпос. Казань: ИЯЛИ, 2015. 448 с. [Urmanche F. I. Tyurkskiy geroicheskiy epos [The Turkic heroic epic]. Kazan: Inst. of Language, Literature and History, 2015. 448 p. (In Rus.)]

Функ 2005 - Функ Д. А. Миры шаманов и сказителей. М.: Наука, 2005. 398 с. [Funk D. A. Miry shamanov i skaziteley [Worlds of shamans and taletellers]. Moscow: Nauka, 2005. 398 p. (In Rus.)]

Хабунова 2006 - Хабунова Е. Э. Стилевая константа «Богатырский поединок» - ключевое звено в биографии эпического героя эпоса «Джангар» // Научная мысль Кавказа. 2006. Спецвыпуск № 3. С. 147-152. [Khabunova E. E. A stylistic constant of 'heroic combat' - a key link in the biography of a hero in the Jangar epic. Nauchnaya mysl' Kavkaza. 2006. Spec. is. 3. Pp. 147-152. (In Rus.)]

Хабунова 2007 - Хабунова Е. Э. Героический эпос «Джангар»: поэтические константы богатырского жизненного цикла: сравнительное изучение национальных версий. Дис... д-ра филол. наук. Элиста, 2007. 310 с. [Khabunova E. E. Geroicheskiy epos «Dzhangar»: poeticheskie konstanty bogatyrskogo zhiznennogo tsikla: sravnitel'noe izuchenie natsional'nykh versiy [The heroic epic of Jan- gar: poetic constants of the hero's life cycle. A comparative study of national versions]. A ScD thesis. Elista, 2007. 310 p. (In Rus.)]

Харузина 1898 - Харузина В. Н. Сказки русских инородцев. М.: Изд. А. И. Мамонтова, 1898. 303 c. [Kharuzina V N. Skazki russkikh inorodtsev [Tales of non-Russians]. Moscow: A. I. Mamontov, 1898. 303 p. (In Rus.)]

Хойслер 1960 - Хойслер А. Германский героический эпос и сказание о Нибелунгах. М.: Изд-во иностр. лит., 1960. 447 с. [Huessler A. Germanskiy geroicheskiy epos i skazanie o Nibelungakh [The German heroic epic and the Song of the Nibelungs]. Moscow: Inostr. Lit., 1960. 447 p. (In Rus.)]

Цийль 1995 - Цийль В. Актуальна ли сегодня «структурная модель волшебной сказки»? // Живая старина, 1995. № 3. С. 27-28. [Tsiyl V. Aktual'na li segodnya "strukturnaya model' volshebnoy skazki"? [Is the "structural model of the magic fairy tale' still relevant today?]. Zhivaya starina. 1995. No. 3. Pp. 27-28. (In Rus.)] Чичеров 1982 - Чичеров В. И. Школы сказителей Заонежья. М.: Наука, 1982. 197 с. [Chicherov V. I. Shkoly skaziteley Zaonezh'ya [The taletelling traditions of Zaonezhye]. Moscow: Nauka, 1982. 197 p. (In Rus.)]

Эрдниев 1985 - Эрдниев У. Э. Калмыки. Элиста: Калм. кн. изд-во, 1985. 282 с. [Erdniev U. E. Kalmyki [The Kalmyks]. Elista: Kalm. Book Publ., 1985. 282 p. (In Rus.)]

Якутские сказки 1990 - Якутские сказки / сост. Сивцев-Суорун Омоллоон, П. Е. Ефремов Якутск: Якутск. кн. изд-во, 1990. 358 с. [Yakutskie skazki [Yakut fairy tales]. SivtsevSuorun Omolloon, P. E. Efremov (comp.). Yakutsk: Jakut Book Publ., 1990. 358 p. (In Rus.)]

Якутские народные сказки 2008 - Якутские народные сказки. Новосибирск: Наука, 2008. 462 c. [Yakutskie narodnye skazki [Yakut folk tales]. Novosibirsk: Nauka, 2008. 462 p. (In Rus.)] 
UDC $398.21+398.22+801.83$

\title{
Criteria to Characterize the Genre of Heroic Fairy Tales and the Key Features to Distinguish between the Latter and Epic Patterns
}

\author{
Aleksey A. Burykin ${ }^{1}$ \\ ${ }^{1}$ Ph.D. in Philology (Doct. of Philological Sc.), Ph.D. in History (Doct. of Historical Sc.), Leading \\ Research Associate, Department of Mongolian Philology, Kalmyk Scientific Center of the RAS (8, \\ Ilishkin St., Elista, 358000, Russian Federation). ORCID: 0000-0002-9119-2698. E-mail: albury@ \\ mail.ru
}

\begin{abstract}
The article examines the correlation between the heroic epic and heroic fairy tales. In many traditions, the two folklore forms are close enough to one another and manifest a number of similarities. The problem brought up is essential to both genre identification of some text patterns and to further discussions over historical interconections between heroic fairy tales and the epic. It is believed that the heroic fairy tale could have been the form to have directly preceded the early epic patterns or had been on of such forms.

Nowadays, scholars note that in certain cases the heroic fairy tale is a result of recent transformation of epic forms to have emerged due to weakened positions of the epic within the existing tradition, reduction in the number of epic patterns as such, progressive loss of epic performance techniques, etc. The paper expresses the opinion that both the epic and the fairy tale - and the heroic fairy tale in particular - had emerged and existed as independent forms with differing attitudes towards the depicted realities: fairy tales are obviously fictitious narratives, while epic texts can potentially describe true events.

The generous 2017 publication of Kalmyk heroic fairy tales makes it possible to outline the key features of such tales and - even more important - to identify essential differences between the genre and epic patterns, namely that of the Jangar. The analysis conducted has shown that structures of Kalmyk heroic fairy tales are more diverse as compared to the introduced (delineated) plot models: many of the declared elements have not been found in the examined texts, and not all fairy tale motifs have been clustered in corresponding models; some features once referred to as those to characterize heroic fairy tales can be attributed to Jangar songs as well. Within the Kalmyk folklore tradition, such heroic tales do retain certain essentially distinct features in relation to the Jangar, though remaining comparable enough in terms of plots and motifs. The article emphasizes both common genre differences between the Jangar and heroic tales, and differences between the forms within the Kalmyk tradition. The multiple common elements of heroic tales and the Jangar (poetic techniques, motifs, formulas, etc.) are attributable to the process of intercommunion between the differing - though semantically similar - forms. The fairy tale versions of Gesar and Jangar songs included in the corpus of Kalmyk heroic fairy tales look like quite recent trasformations of epic patterns. The Jangar and heroic tales are approximately similarly abundant in Buddhist realia which signifies their traditional unity; but Jangar songs still contain pre-Buddhist religious beliefs. The study concludes that the genre group of heroic tales basically retains the structure pattern inherent to the magic fairy tale and determined following V. Propp's functions; the main character of heroic tales is more individualistic in his deeds and goals as compared to epic heroes, and unlike the case with Jangar Bogdo, such fairy tale heroes bear no function of social organization.
\end{abstract}

Keywords: folklore, folklore studies, genres, epic, fairy tales, heroic fairy tales, Kalmyks 